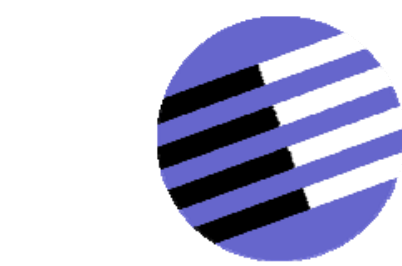

GOVERNANCE AND THE EFFICIENCY

OF ECONOMIC SYSTEMS

GESY

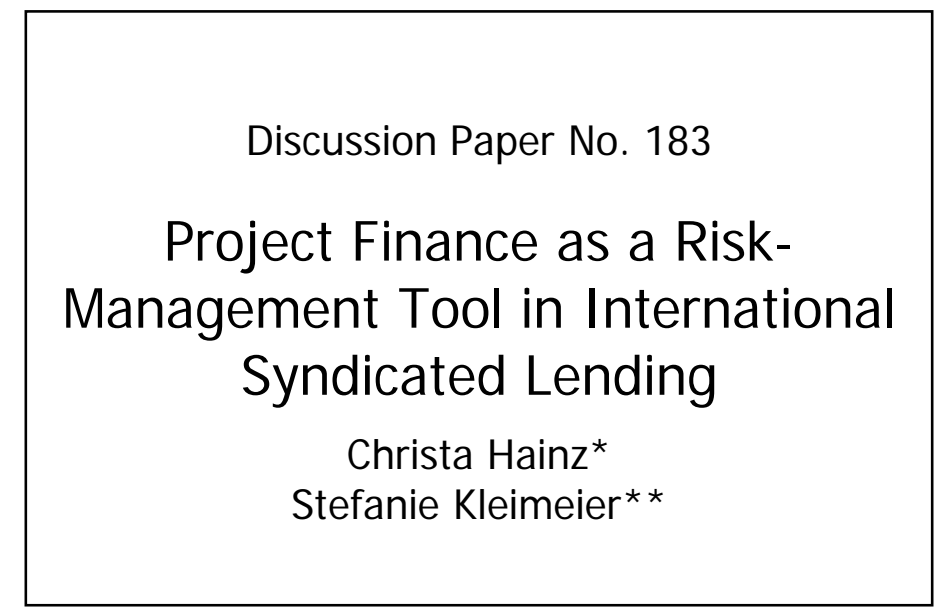

December 2006

*Christa Hainz, Department of Economics, University of Munich, Akademiestr. 1/III, 80799 Munich. christa.hainz@lrz.uni-muenchen.de

**Stefanie Kleimeier, Limburg Institute of Financial Economics, FdEWB, Maastricht University,

P.O. Box 616, 6200 MD Maastricht, Netherlands. s.kleimeier@finance.unimaas.nl

Financial support from the Deutsche Forschungsgemeinschaft through SFB/TR 15 is gratefully acknowledged.

Sonderforschungsbereich/Transregio $15 \cdot$ www.gesy.uni-mannheim.de 


\title{
Project Finance as a Risk-Management Tool in International Syndicated Lending
}

\author{
Christa Hainz ${ }^{\#}$ \\ University of Munich \\ Stefanie Kleimeier* \\ Maastricht University
}

\begin{abstract}
$\underline{\text { Abstract }}$
We develop a double moral hazard model that predicts that the use of project finance increases with both the political risk of the country in which the project is located and the influence of the lender over this political risk exposure. In contrast, the use of project finance should decrease as the economic health and corporate governance provisions of the borrower's home country improve. When we test these predictions with a global sample of syndicated loans to borrowers in 139 countries, we find overall support for our model and provide evidence that multilateral development banks act as "political umbrellas".
\end{abstract}

JEL-Classification: D82, F34, G21, G32

Keywords: $\quad$ Project finance, syndicated loans, political risk, double moral hazard.

\# Christa Hainz, Department of Economics, University of Munich, Akademiestr. 1/III, 80799 Munich, Germany, phone: +49-89-21803232, e-mail: christa.hainz@lrz.uni-muenchen.de

* Stefanie Kleimeier, Limburg Institute of Financial Economics, FdEWB, Maastricht University, P.O. Box 616, 6200 MD Maastricht, The Netherlands, phone: +31-43-3883733, email: s.kleimeier@finance.unimaas.nl

The authors would like to thank Franz Benstetter, Elena Carletti, Stefano Gatti, Clara Graciano, Carola Grün, Victoria Ivashina, Isabelle Kronawitter, Luc Laeven, William Megginson, Sven Rady, Monika Schnitzer, Koen Schoors, and participants of the Annual Meeting of the German Economic Association Magdeburg, the 2nd Workshop of Applied Infrastructure Research at the Technical University of Berlin, the Research Seminar of the Institute of Capital Market Research and Finance at the University of Munich, the XII International "Tor Vergata” Conference on Banking and Finance in Rome, the First Conference of the Financial Intermediation Research Society in Capri, the EFA Meeting in Maastricht, the LIFE seminar at the University of Maastricht and the Economics Workshop at the University of Tübingen for helpful comments and suggestions. The usual disclaimer applies. Christa Hainz gratefully acknowledges financial support from the German Science Foundation, under SFB-Transregio 15 and from FOROST. 


\section{Introduction}

When looking at the global distribution of syndicated loans, we observe that firms in countries with high political risk receive relatively few loans, and that many of these loans are structured as limited-recourse project finance. The low number of loans can be understood in the context of the law and finance nexus, which states that there is a positive correlation between creditor rights and financial intermediation (Djankov, McLiesh, and Shleifer, 2007). The prominence of project finance can be explained by the use of private contracting that mitigates the risks arising from poorly functioning institutions in the host country (Qian and Strahan, 2005). Although these concepts may help to explain the use of project finance in general, several questions remain unanswered, such as when is it optimal to grant a project finance loan? How does the degree of recourse influence the incentives of lenders and borrowers to manage risks? When multilateral development banks are part of the syndicate, what role do they play in mitigating risk, particularly political risk?

In this study, we follow Esty (2004) and define "project finance" as the creation of a legally independent project company that is financed with equity from one or more sponsoring firms, and which has non- or limited recourse debt for the purpose of investing in a capital asset. We investigate the relationship between syndicated lending and the management of political and corporate risks. To answer the questions we pose above, we develop a double moral hazard model and test its predictions by using a global sample of syndicated and project finance loans made to borrowers in 139 countries between 1991 and 2005.

Our theoretical model analyzes the terms of a private loan contract in a set-up in which the borrower must exert effort in order to manage the firm, and the lender is able to mitigate political risk. Generally, we show that there is a trade-off between the incentives for the borrower and the lender when they determine the degree of recourse. We find that borrowers prefer project 
finance loans if the corporate governance system in a country is weak, economic health is poor, and political risk and bank influence are high. In the empirical part of our study, we also test which type of lender or syndicate is actually able to mitigate political risk in practice. Thus, our study provides evidence for the way political risk can be mitigated through a loan contract, i.e., through the inclusion of multilateral or national development banks in the syndicate.

The gas field project that the South African petrochemical group Sasol is currently developing in Mozambique illustrates how contracts can be designed to mitigate political risk. To finance the deal, Sasol opted for a unique hybrid project finance structure. Initially, lenders have full recourse to Sasol, which assumes almost all project related risks. The sole - but important exception is the project's political risk. Here, the loan contract specifies that if well-defined political risk events occur, the lenders have the right to switch from the full-recourse structure to a project-financing structure. The lenders, in particular the development banks that fund more than half of the loan, requested that this hybrid structure be created. Cadwalader (2004), the project's legal consultant, interprets this structure as a commitment device of the development banks to actively mitigate the political risk: "Sasol would like to maximize the influence that the political risk providers $[\ldots]$ bring to the deal - their ability to exert political pressure on, in this case, Mozambican government to prevent or cure a political risk event. Limiting the ability of the lenders, and effectively of the subrogated insurers, to pull the proverbial rug from underneath the project (by limiting the lenders' acceleration and enforcement rights) is arguably the most effective way of insuring that such institutions actively seek to remedy or mitigate any political risk event $[\ldots] . "$

We provide a systematic analysis of the relationship between political risk, its mitigation by lenders, and the type of loan, e.g., the degree of recourse under the loan contract. Thus, our study relates to the empirical and theoretical literature on syndicated loans in general and on project 
finance loans in particular, and also to papers on the relationship between law and finance. Since we study the incentive effects of different loan types for borrowers and lenders, our paper is also related to the theoretical literature on bank moral hazard and double moral hazard.

Most empirical studies on project finance are limited to loan-pricing studies or syndicatestructure analysis Despite the fact that the focus of these studies is quite different from our own, these studies provide clear evidence for the relevance of political risk. All loan-pricing studies agree that political risk, either directly or indirectly via a political risk guarantee, is reflected in the spread of the loan. Kleimeier and Megginson's (2000) study also indicates that the higher the political risk of the host country the more likely is project finance.

Esty and Megginson (2003) investigate the syndicate structure of project finance loans in the context of legal quality, which, though not identical to political risk, is clearly related to it. These authors find that for borrowers in countries with weak creditor rights and poor legal enforcement, syndicates must be particularly large and diffuse in order to deter strategic default. In contrast, in countries with strong and enforceable legal rights, syndicates are structured to ensure monitoring and low-cost recontracting. Thus, the syndicate structure is a direct response to risk. Qian and Strahan (2005) present similar results. These authors argue that the design of private loan contracts is determined by the legal and institutional characteristics of a country.

Among the few theoretical papers on project finance, none addresses the issue of political risk in the context of borrower and lender incentives. Shah and Thakor (1987) and John and John (1991) model project finance based on the tax advantage of debt, and Chemmanur and John (1996) focus on private benefits of control. Habib and Johnson's (1999) model is driven by the redeployability of assets. Laux (2001) argues that project finance can be used as a commitment devise by the headquarters to monitor the quality of the project and to influence the project 
manager's incentives. Our study is thus the first that models project finance as an instrument to optimally align both borrower and lender incentives.

Moral hazard papers study different types of bank moral hazard depending on the tasks assigned to the bank. Rajan and Winton (1995) investigate the bank's incentive to gather unverifiable information on the future prospects of the firm after credit is granted. Manove, Padilla, and Pagano (2001) study the bank's incentive to exert costly effort for screening projects ex ante. More realistically, the bank's as well as the firm's efforts are unobservable, so there is a double moral hazard problem. If the double moral hazard problem exists because the bank has to monitor the effort of the firm, then it is optimal to finance firms by a mix of bank credit and external capital (Besanko and Kanatas (1993)). Double moral hazard also arises in venture capital arrangements in which the entrepreneur and the venture capitalist must exert effort (Schmidt, (2003)). Neither pure equity finance nor pure debt finance solves both problems simultaneously. Instead, a convertible security with an appropriately set price gives both parties an incentive to exert first best effort.

The empirical studies on project finance highlight the prominent role of political risk. Our paper systematically analyzes how political risk is mitigated through private contracting that is designed such as to solve the double moral hazard problem. Our study provides empirical support for the notation that multilateral development banks act as "political umbrellas".

Our study proceeds as follows. Section 2 presents our model with the double moral hazard problem. We analyze the incentives that result from different degrees of recourse for both lenders and borrowers. In section 3, we derive empirically testable hypotheses. We interpret the effort of the lender as an effort made to influence political risk, and the effort of the borrower as an effort made to increase the profitability of the project. We present the data sources in section 4. Section

\footnotetext{
${ }^{1}$ Loan pricing studies include Sorge and Gadanecz (2004), Nguyen and Ross (2002), Kleimeier and Megginson
} 
5 provides a description of the global use of project finance and discusses our empirical results. Section 6 concludes.

\section{A Double Moral Hazard Model of Project Finance}

We discriminate different modes of bank finance, i.e., full-recourse syndicated loan versus project-finance loans. A project-finance loan can either be a limited-recourse loan that allows lenders some recourse to the sponsors, in the form of, for example, additional equity or the reduction of dividend or royalty payments; or a non-recourse loan that gives lenders no recourse to the sponsors.

\subsection{The Basic Model}

A firm wants to finance a project, which yields a payoff of $X>0$ in the case of success and zero in the case of failure. We assume that the project's assets have a liquidation value of zero. The project costs I. We assume that the firm finances the investment project through credit. The probability of the project's success $\mathrm{p}$ is determined by the effort of the firm, denoted by e, and by the effort of the bank, denoted by b. We assume that the impact on the probability of success is independent of the action of the respective other agent, so we do not model the bank in its traditional role as a monitor.

If the firm's manager exerts effort e, the probability of success increases from $\underline{p}$ to $\bar{p}$. Similarly, if the bank decides to exert effort $b$, the probability of success increases from $\mathrm{p}_{\mathrm{L}}$ to $\mathrm{p}_{\mathrm{H}}$. Accordingly, the probabilities of success can be $\overline{p_{H}}, \overline{p_{L}}, \underline{p_{H}}$ or $\underline{p_{L}}$. The sponsoring firm that decides on the realization and financing of a new project has wealth of $\mathrm{W}$. This wealth includes

(1998, 2000, 2002), Ivashina (2005). Esty and Megginson (2003) and Sufi (2006) analyze the syndicate structure. 
all assets of the firm and the cash flows generated by all other projects of the firm. We assume that assets are not firm specific.

The time line is as follows: The firm decides whether to incorporate the project within the sponsoring firm or separately. At time 0, the bank offers a selection of credit contracts. All contracts specify the repayment $\mathrm{R}$ in the case of success and $\mathrm{V}$ in the case of failure, where $\mathrm{V}$ is determined by the bank's degree of recourse. The firm chooses the contract, which is then signed by the bank and the firm. Next, both the firm and the bank can exert effort. At time 1, the payoff of investment, i.e., $\mathrm{X}$ or zero, is realized and the bank receives repayment $\mathrm{R}$ in the case of success or $\mathrm{V}$ in the case of failure.

The decision on how to incorporate the project determines the debtor's liability and the bank's degree of recourse, and therefore the bank's payoff if the project fails. If the project is incorporated separately, unless the sponsor grants limited recourse it receives a non-recourse credit. If the project is incorporated within the sponsoring firm, the bank grants a traditional fullrecourse credit. Table 1 shows that in the case of full recourse, the bank receives $\mathrm{R}$ even if the project fails and generates a payoff of zero. However, in the case of limited or non-recourse credit, the bank only receives $\mathrm{V}$ if the project fails with $\mathrm{X}>\mathrm{V}>0$ in the limited-recourse case, and $\mathrm{V}=0$ in the non-recourse case.

[Insert Table 1 about here]

We restrict the analysis to welfare-increasing projects characterized by the assumption

$$
p(e, b) X-I-e-b \geq 0 \text {. }
$$

In a first-best world with symmetric information, the effort levels of both the firm and the bank can be observed and verified by the court, and therefore stipulated in a contract. In practice, these 
effort levels are not contractible. Thus, the credit contract must be designed so that both parties have an incentive to exert effort. However, in a world with asymmetric information, the incentives of both bank and borrower depend on the terms of the credit contract. With a nonrecourse loan, the firm has an incentive problem, because the expected net return for the firm's manager is lower than its effort costs:

$$
(\overline{\mathrm{p}}-\underline{\mathrm{p}})\left(\mathrm{X}-\frac{\mathrm{I}}{\overline{\mathrm{p}}}\right)<\mathrm{e}
$$

Nevertheless, it is socially efficient to exert effort, because we assume that the increase in the expected returns exceeds the costs of effort, i.e. $(\overline{\mathrm{p}}-\underline{\mathrm{p}}) \mathrm{X}>\mathrm{e}$. Furthermore, we assume that it is possible to solve the bank's moral hazard problem if it grants a non-recourse loan, since the highest expected return from exerting effort covers the bank's effort costs:

$$
\left(p_{H}-p_{L}\right) \frac{I}{p_{H}}>b .
$$

We solve the game by backward induction. We assume that the banking sector is perfectly competitive; thus, banks make zero expected profit. Firms chose the contract that maximizes their payoff from the selection of contracts. First, we must study which type of contract solves the bank's moral hazard problem, then we must analyze which loan contract solves the firm's moral hazard problem. Only then can we focus on the double moral hazard case to show which type of contract is optimal.

\subsection{The Moral Hazard Problem of the Bank}

The bank can increase the probability of success by exerting effort $b$. It decides to do so if

$$
\begin{aligned}
& p_{H} R+\left(1-p_{H}\right) V-b \geq p_{L} R+\left(1-p_{L}\right) V \\
& \text { or } \\
& \left(p_{H}-p_{L}\right)(R-V) \geq b .
\end{aligned}
$$


The incentive compatibility constraint of the bank (IC-B) in (4) is more easily fulfilled if the difference between the bank's payoffs in the case of either the success or failure of the project is

high. Consequently, increasing $\mathrm{R}$ and simultaneously decreasing $\mathrm{V}$ improves the bank's incentive to exert costly effort. We restrict our analysis to parameters that fulfill the bank's participation constraint (PC-B), given by:

$$
\overline{\mathrm{p}_{\mathrm{H}}} \mathrm{R}+\left(1-\overline{\mathrm{p}_{\mathrm{H}}}\right) \mathrm{V}-\mathrm{I}-\mathrm{b} \geq 0
$$

Proposition 1: The moral hazard problem of the bank can always be solved by granting a nonrecourse credit, i.e. $\mathrm{V}=0$.

Proof: See Appendix A.

By incorporating the project separately, the firm is not liable at all if the project fails. Therefore, the difference between the bank's payoffs for either success or failure is high, and the bank has an incentive to exert effort. If it is not possible to induce the bank to exert effort by separately incorporating the project, then the moral hazard problem of the bank cannot be solved. We exclude this possibility by assumption (3). Of course, if the moral hazard problem of the bank is less severe, i.e., $\left(\mathrm{p}_{\mathrm{H}}-\mathrm{p}_{\mathrm{L}}\right)(\mathrm{R}-\mathrm{V}) \geq \mathrm{b}$, then both non-recourse and limited-recourse credits solve the incentive problem.

\subsection{The Moral Hazard Problem of the Firm}

The firm's manager must also decide whether to exert effort e. Therefore, the management considers the expected payoff that is influenced by the probability of success, the repayment $\mathrm{R}$ in the case of success, and the repayment $\mathrm{V}$ in the case of failure. Effort is exerted if 


$$
\begin{aligned}
& \bar{p}(W+X-R)+(1-\bar{p})(W-V)-e \geq \underline{p}(W+X-R)+(1-\underline{p})(W-V) \\
& \text { or } \\
& (\bar{p}-\underline{p})(X-R+V) \geq e .
\end{aligned}
$$

By inspecting the incentive constraint of the firm (IC-F) of Eq. (6) in more detail, we obtain the following implication for its liability.

Proposition 2: The moral hazard problem of the firm can always be solved by making the borrower fully liable, i.e., $\mathrm{R}=\mathrm{V}$.

Proof: See Appendix A.

By increasing the debtor's liability, his payoff in the case of failure is reduced, and the difference in state-contingent payoffs of the firm increases. Thus, the credit contract provides an incentive to the firm to exert effort. If the moral hazard problem of the firm is less severe, i.e., $(\bar{p}-p)(X-R+V) \geq e$, then the first-best solution can be reached with limited or fullrecourse credit.

\subsection{Double Moral Hazard}

The empirical facts suggest that both banks and firms have to contribute to the success of an investment project. Propositions 1 and 2 show that the debtor's liability influences both the bank's and the firm's incentive to exert costly effort. On the one hand, limited recourse increases the bank's incentive. On the other hand, limited recourse has a negative impact on the firm's incentive. 
Proposition 3: If both incentive problems are less severe, i.e., $X \geq \frac{1}{\overline{p_{H}}-\underline{p_{H}}} e+\frac{1}{\overline{p_{H}}-\overline{p_{L}}} b$, $\left(\mathrm{p}_{\mathrm{H}}-\mathrm{p}_{\mathrm{L}}\right)(\mathrm{R}-\mathrm{V}) \geq \mathrm{b}$ and $(\overline{\mathrm{p}}-\underline{\mathrm{p}})(\mathrm{X}-\mathrm{R}+\mathrm{V}) \geq \mathrm{e}$, limited recourse, i.e., $\mathrm{R}>\mathrm{V}>0$, solves the double moral hazard problem.

Proof: See Appendix A.

If the incentive problems are not severe, the bank can design a credit contract that solves both incentive problems. The exact terms of the credit contract depend on how slack the incentive compatibility constraints are. Since we assume that banking is perfectly competitive, the contract always generates an expected profit of zero to the bank, i.e.,

$$
\overline{\mathrm{p}_{\mathrm{H}}} \mathrm{R}+\left(1-\overline{\mathrm{p}_{\mathrm{H}}}\right) \mathrm{V}-\mathrm{I}-\mathrm{b}=0 \text {. }
$$

Therefore, the relationship between $\mathrm{R}$ and $\mathrm{V}$ is deduced as

$$
\mathrm{R}=\frac{\mathrm{I}+\mathrm{b}-\left(1-\overline{\mathrm{p}_{\mathrm{H}}}\right) \mathrm{V}}{\overline{\mathrm{p}_{\mathrm{H}}}}
$$

If the bank's incentive compatibility constraint but not the firm's incentive compatibility constraint is binding, the credit contract stipulates

$$
\left\{\mathrm{R}=\mathrm{I}+\mathrm{b} \frac{1-\overline{\mathrm{p}_{\mathrm{L}}}}{\overline{\mathrm{p}_{\mathrm{H}}}-\overline{\mathrm{p}_{\mathrm{L}}}} ; \mathrm{V}=\mathrm{I}-\mathrm{b} \frac{\overline{\mathrm{p}_{\mathrm{L}}}}{\overline{\mathrm{p}_{\mathrm{H}}}-\overline{\mathrm{p}_{\mathrm{L}}}}\right\}
$$

Both the bank and the firm have an incentive to exert effort only if the condition stated in proposition 3 holds. For all other parameter constellations it is impossible to design a contract that solves both moral hazard problems. In such cases, the contract should grant an incentive to the party for whom the moral hazard problem is solved most efficiently. In the following proposition we state which of the moral hazard problems should be solved. 
Proposition 4: If it is not possible to solve both incentive problems, i.e.,

$$
X<\frac{1}{\overline{p_{H}}-\underline{p_{H}}} e+\frac{1}{\overline{p_{H}}-\overline{p_{L}}} b
$$

and the moral hazard problem of the firm is severe, i.e.,

$$
\left(\underline{p_{H}}-\underline{p_{L}}\right) X-b>\left(\overline{p_{L}}-\underline{p_{L}}\right) X-e
$$

then it is optimal to solve the incentive problem of the bank through project finance by separately incorporating the new project and via granting a non-recourse credit, i.e., $\mathrm{V}=0$.

Proof: See Appendix A.

For most parameter constellations, it is not possible to design a contract that gives both parties appropriate incentives. Therefore, the optimal contract solves the incentive problem of the party whose effort has a relatively higher impact on the probability of success. Therefore, it is optimal to solve the bank's incentive problem if $\left(\underline{p_{H}}-\underline{p_{L}}\right) X-b>\left(\overline{p_{L}}-\underline{p_{L}}\right) X-e$. For example, if e and $b$ have the same size and $b$ increases the probability of success more than e, then it is optimal to give the bank the incentive to exert effort.

To induce the bank to exert effort, the difference between the payoffs for success and failure must be high. The credit contract can stipulate a sufficiently high difference between the state-contingent payoffs when the new investment project is separately incorporated. Then, the bank receives no return in the case of failure, as the project's payoff is zero and there is no recourse on the assets of the firm that sponsors the project. 


\section{Testable Hypothesis}

Our model defines the effort of both the bank and the firm only generally, and thus leaves room for different types of effort. Since the focus of our study is on risk management, we apply the propositions that arise from our theoretical model to the firm's and bank's effort in managing risks. As noted earlier, our only assumption on the efforts of bank and firm is that the influence of one on the probability of success of the project is independent of the actions of the other. In our model we assume that the bank exerts effort to mitigate political risk, and that the manager makes an effort to improve the firm's operational performance. For example, the manager determines the technical realization of the project. The bank, which has many ways in which it can influence the probability of the project's success, might, for example, try to influence government decisions, or it might assist the firm in obtaining access to markets or experts like an auditor.

We base our empirical analysis on Proposition 4, because we perceive that in reality the incentive problems are severe. We use the notation of our model to phrase the incentive problems we intend to study. The bank's moral hazard problem arises because a bank must exert effort, which causes costs of $b$ in order for the bank to reduce political risk, which is captured by $\left(p_{H}-p_{L}\right)$. The firm's moral hazard problem arises because a firm must exert effort, which

causes costs of e, in order for the firm to increase the probability of success from $\underline{p}$ to $\bar{p}$. For a more detailed derivation, we note that Proposition 4 predicts that project finance should be the preferred financing choice when

$$
\left(p_{H}-p_{L}\right) X-b>\left(\overline{p_{L}}-\underline{p_{L}}\right) X-e \Leftrightarrow \frac{\left(p_{H}-p_{L}\right) X-b}{\left(\overline{p_{L}}-\underline{p_{L}}\right) X-e}>1 .
$$

An economic interpretation of this project finance preference ratio (PFP ratio) relates the use of project finance to four factors. These factors capture the firm's and the bank' incentive problems in the following way: 
The firm's moral hazard problem is reflected by the denominator of the PFP ratio, and here by the influence of managerial effort on the probability of success, given by $\left(\overline{p_{L}}-\underline{p_{L}}\right)$, in relation to the manager's effort costs e. We believe that in countries with a healthy economy, a given level of effort changes the success probability more than would the same effort in a country with a weak economy. In other words, the higher is $\left(\overline{p_{L}}-\underline{p_{L}}\right)$, the better the economic health and performance of a country. As the PFP ratio decreases with an increase in $\left(\overline{p_{L}}-\underline{p_{L}}\right)$, we should observe a negative relation between economic health of the borrower's country and the use of project finance.

Furthermore, the effort a firm's manager must exert to manage a corporation causes costs of e. In an international comparison, we would expect the costs of effort to be higher in countries with less effective corporate governance systems. (We note that the absolute size of effort costs can be interpreted as private benefits. In countries with poor corporate governance, effort costs are high and so are private benefits.) In these economies, there are far fewer restrictions and punishments if a manager deviates from the best corporate strategy. Ceteris paribus, the firm's moral hazard problem is greater in countries with a poor corporate governance system. Given that a better corporate governance system implies lower effort costs e, and given that the PFP ratio decreases with a decrease in e, we expect a negative relation between the quality of the corporate governance system and the use of project finance.

The numerator of the PFP ratio reflects the bank's moral hazard problem. Here, $\left(\mathrm{p}_{\mathrm{H}}-\mathrm{p}_{\mathrm{L}}\right)$ reflects the change in the probability of success when the bank exerts effort, and b reflects the cost associated with this effort. We interpret $\left(\mathrm{p}_{\mathrm{H}}-\mathrm{p}_{\mathrm{L}}\right)$ in the context of political risk. The more the government's actions can influence the probability of the success of a project, the higher the difference between $p_{H}$ and $p_{L}$ will be. On the one hand, the probability of success of the project 
without any effort by the bank, $\mathrm{p}_{\mathrm{L}}$, will be low in countries with high government involvement and high political risk. On the other hand, once the bank exerts effort, the success probability of the project will be significantly increased. Thus, high political risk increases the numerator, and we expect a positive relation between political risk and the use of project finance.

The bank's influence on the host government is reflected in b. The higher the bank's influence on the host government, the lower is the cost of $b$ at which a given increase in the project's success probability will be achieved. In other words, the lower the b, the cheaper it is for a bank to constrain politically adverse moves. Therefore, we expect a positive relation between bank influence (measured by a smaller $b$ ) and the use of project finance.

To illustrate the role of banks of our model, consider the following situation: If the government perceives that apart from the investment project under consideration, a bank is important to the country, it might be more reluctant to engage in actions against the project compared to a situation in which the government does not fear far-ranging consequences of its actions. The government could, for example, be concerned that negative actions on one project could spill over onto other projects financed by the same bank. From the bank's point of view, any effort will be less costly if the bank is relatively important to the government and country. Among all lenders, multilateral development banks such as the International Financial Corporation (IFC), a member of the World Bank Group, or the European Bank for Reconstruction and Development (EBRD) have high bargaining power because they finance many projects and also provide financial aid. Thus, there is repeated interaction between the development bank and the host government.

In contrast to commercial banks that might also be frequent lenders, the development banks (DBs) have a special status. Buiter and Fries (2002) argue that multilateral development banks differ from other lenders because their “(...) support for private sector projects can be 
instrumental in mitigating risks associated with government polities and practices". Therefore, multilateral DBs are also known as political umbrellas (see Buljevich and Park, 1999). For these reasons, we expect that the bank's ability to exert effort and consequently its effort cost b will depend on its status as a DB as well as on its market share in the syndicated loan market. Considering all these factors, we propose the following testable hypothesis:

Testable Hypothesis: Among all syndicated loans made to borrowers in a country, the fraction of project finance loans is larger, the weaker the corporate governance system, the weaker the economic health, the higher the political risk of the borrower's country and the higher the influence of the lending bank over the host government.

\section{Data}

Our main data source is the Dealscan database. To obtain a proxy for our dependent variable, we extract from Dealscan all syndicated loans (SLs) signed between January 1, 1991 and December 31, 2005. By controlling for the borrower's nationality and the type of syndicated loan, we can define the project finance share as

$$
\mathrm{PFL}_{-} \mathrm{vol}_{\mathrm{i}}=\frac{\mathrm{PFL}_{\mathrm{i}}^{\$}}{\mathrm{SL}_{\mathrm{i}}^{\$}} * 100
$$

where $\mathrm{PFL}_{\mathrm{i}}{ }_{\mathrm{i}}$ is the total volume of project finance loans (PFLs) in $\$$ million of all borrowers of country $i$ and $\mathrm{SL}_{\mathrm{i}}^{\$}$ is the total volume of SL in $\$$ million of all borrowers of country $i$.

First, we note that this measure of our dependent variable is consistent with our assumption that the investment project is credit financed, and with our differentiation between

different types of bank finance. $\mathrm{SL}^{\$}$ i reflects all investments that managers finance with bank credit. These include full-recourse syndicated loans as well as limited- or non-recourse PFLs. 
Using these factors makes it possible for our empirical analysis to explain how large the share of PFLs is.

Second, we aggregate all loans to borrowers of the same country over time. Because not all countries access the syndicated loan market every year, the number of panel-observations ranges from one to 15 per country. Furthermore, for many of the panel observations, the value of the dependent variable is zero. This is often the case for countries with a low number of SLs per year. We opt for the pooled approach, because we have a sufficiently large number of countries in our sample. However, we do conduct robustness checks based on a panel data set for those countries that enter the syndicated loan market every year.

We obtain the proxies for our four explanatory factors from Dealscan, Euromoney, and the World Bank. Since the firm's moral hazard problem depends on how much an increase in the manager's effort will raise the success probability of a project, given the manager's effort cost, we need two country-level variables to measure these two components of firm moral hazard. Earlier, we noted that a manager's influence on the probability of success depends on the economic health of a country, meaning that a given effort has a larger effect in a country with better economic perspectives. We use Euromoney's economic performance index as our proxy for the economic health of the borrower's country. This annual index is based on the current GDP per capita figures and on a poll of economic projections. Thus, it contains not only current but also forward-looking information, which is especially useful to us when we consider the medium to long-term nature of syndicated loans. To aggregate this variable over time, we use an equally weighted average over all years. Furthermore, we convert the original scale of this proxy from zero to 25 to zero to 100 . A higher value indicates better economic performance and health.

We also noted earlier that the firm's effort costs depend on the country's corporate governance system, which means that the weaker the corporate governance system, the higher is 
the manager's opportunity cost (lost private benefits or perquisites) of pursuing the best corporate strategy. As a proxy for the strength of the corporate governance system, we use a measure of financial development that combines the development of the stock market and the banking system. We define corporate governance as the equally weighted average of stock market capitalization and domestic credit to the private sector, both as a percentage of GDP. We obtain both values from the World Bank's World Development Indicators (WDI). A higher value indicates better corporate governance, because managers in countries with a more developed financial sector are more controlled by active stockholders and bank lenders than are managers in countries with less developed financial sectors. Thus, this measure captures the strength of the corporate governance system in terms of market forces. Similar to our economic health proxy, we average the annual values. Because we measure both components of the corporate governance proxy as percentages, we do not rescale this variable.

The bank's moral hazard problem also consists of two components, political risk and bank influence, for which we need country-level proxies. We note that political risk can be divided into three broad categories: traditional political risk, regulatory risk, and quasi-commercial risk (Smith 1997). The traditional political risk category addresses risks relating to expropriation, currency convertibility, and transferability, and to political violence. The regulatory risk category covers risks arising from unanticipated regulatory changes. These risks include taxation or foreign investment laws applicable to the whole economy, but can also be industry specific. The quasicommercial risk category reflects those risks that arise when the project contends with stateowned suppliers or customers whose ability or willingness to fulfill their contractual obligations towards the project is questionable.

We consider traditional political risk and regulatory risk when we interpret bank moral hazard. The World Bank's Worldwide Governance Research Indicators Data Set specifies six 
measures of political risk that fit our perception of these risk categories. These measures are the voice and accountability of the government, political stability, government effectiveness, regulatory quality, rule of law, and control of corruption. This data set covers all countries in our sample, but its time coverage is limited to $1996,1998,2000,2002$, and 2004. As our main proxy, we use a combined average of all six measures. We apply simple averages and rescale the resulting proxy from zero to 100 . A higher value indicates more political risk. For a more detailed analysis, we also look at each of these six measures separately.

As the second component of the bank's moral hazard problem we measure the lender's influence over the host government, which, as noted earlier, depends on both the lender's status as a DB and its market share in the SL market. First, we obtain national league tables for SLs signed between 1991 and 2005 for each country i from Dealscan. These tables rank all lenders based on the amount of funds they provide during our sample period, which allows us to identify exactly which lender provides how many funds to each country. Second, we classify lenders as DBs based on the World Bank's definition of multilateral development banks and multilateral financial institutions. We define our measure of bank influence as the aggregate market share of these DBs in the SL market and as such combine lender status and market share in our proxy. We measure the market share of DBs as their total syndicated loan volume to borrowers of country $\mathrm{i}$ relative to the total syndicated loan volume of all lenders to borrowers of country i. A higher value indicates more bank influence.

For a detailed analysis, we also measure a lender's individual market share and extend our analysis to prominent national DBs, such as export-import banks. We include these latter lenders if they have a substantial share in the SL market and might therefore have substantial influence over the host government. Based on Dealscan's league table for global SLs signed between 1991 and 2005, we select those national DBs that fund at least 100 SLs which are worth $\$ 1,000$ bn. 
Table 2 lists the individual DBs and indicates to which category they belong ${ }^{2}$ Among them, the European Bank for Reconstruction and Development (EBRD) and Germany's Kreditanstalt für Wiederaufbau (KfW) are the most prominent lenders, followed by the Japan Bank for International Cooperation (JBIC). There is no clear link between a DB's total loan volume and the share of PF in its loan portfolio. For example, the PFL-share is high for the firstranked EBRD but low for the second-ranked KfW. Overall, loan volume alone does not imply a preference for project finance.

[Insert Table 2 about here]

\section{The Global Market for Syndicated Loans, Project Finance, and Political Risk}

\subsection{The Use of Project Finance}

Between January 1991 and December 2005, companies from 139 countries raised funds in the global syndicated loan market, amounting to 119,779 facilities worth $\$ 24,778$ billion ${ }^{3}$ As Table 3 shows, 5,282 of these facilities are PFLs worth $\$ 941$ billion, which lenders allocated to borrowers from 108 countries. As expected, borrowers in industrialized countries receive most SLs. Western Europe, North America, and Australia alone account for $87 \%$ of the global SL volume. Looking at a country's PFL borrowing relative to its total SL borrowing indicates that PFLs are not a very important source of funds for corporate borrowers in industrialized countries. For example, in North America and Western Europe, 3\% or less of the total SL volume is in form of PFL.

\footnotetext{
${ }^{2}$ The table also identifies which lenders we include in our bank influence proxy. When discussing empirical results related to this bank influence proxy, we will refer to these lenders in general terms as development banks (DBs). Only when we conduct the detailed analysis of individual lenders will we specifically refer to the different lender categories.

${ }^{3}$ Dealscan actually contains loans to borrowers from 145 countries, but we deleted six countries (Bermuda, British Virgin Islands, Brunei, Cayman Islands, Iraq, and Taiwan) due to missing values for our four main proxies. These countries account for an additional 2,395 SL facilities worth $\$ 320,566$ million.
} 
Australia is an exception with 15\%, as are individual western European countries such as Greece and Portugal. Borrowers from Latin America, Eastern Europe, the Middle East, Africa, and Asia display a reverse pattern. For most of these countries, the volume of PFLs relative to all national SLs is at least three times, and at most ten times, as high as the global average. In the most extreme cases of Cameroon, Nepal, and Uganda, PFLs account for $100 \%$ of the national SL volume, followed by Liberia, Tajikistan, and Bosnia Herzegovina with more than $80 \%$.

Overall, it appears that countries with high shares of PFLs represent corporate borrowers from countries with higher political risk, lower economic performance, and less access to credit or equity finance. This observation gives us our first indication that risk influences the decision of banks and borrowers on PF over on-balance-sheet lending.

[Insert Table 3 about here]

Fig. 1 and Table 4 provide further support for the overall relevance of risk for PF. Here we use a very general, comprehensive measure of risk, Euromoney's country risk score, which comprises both economic and political risk. Fig. 1 presents our individual country observations and shows a clear pattern of more project finance when there is higher country risk. In Table 4, we split our total sample into quartiles based on this country risk score and compare the different levels of SL and PFL usage. These quartiles confirm the results of Fig. 1. As risk increases from low to moderately low, the relative use of PFL rises from about $7.1 \%$ to $22.5 \%$. For countries with moderately high and high political risk, PF becomes even more important as a source of financing, amounting to $32.2 \%$ and $24.8 \%$, respectively. To illustrate the strength of our results, we note that for two of the four quartiles, the mean values for two consecutive quartiles are 
significantly different based on a one-sided z-test. The difference is most pronounced for the two low country-risk quartiles and could imply a somewhat nonlinear relation between the use of PF and risk.

[Insert Fig. 1 and Table 4 about here]

\subsection{The Relevance of Bank and Firm Moral Hazard}

To test our hypothesis, we first use our four main proxies for bank and firm moral hazard. Regressions (1) to (5) in Panel A of Table 5 present the results. Based on our hypothesis, we expect to find that $\mathrm{PF}$ is used more often when the bank influence is stronger and political risk and the economic health and corporate governance system are weaker. In the single regressions (1) to (4), all slope coefficients are significant and have the expected signs. The coefficients' size shows that a $10 \%$ increase in bank influence, i.e., market share of DBs, leads to $4.8 \%$ more PF, and a $10 \%$ increase in political risk leads to $6.8 \%$ more PF. The coefficients of our firm moralhazard proxies are somewhat smaller. Here, a 10\% improvement in economic health or corporate governance leads to $3.2 \%$ and $1.9 \%$ less PF, respectively. Combined with the explanatory power in terms of adjusted $\mathrm{R}^{2}$, it appears that bank moral hazard, and particularly political risk, is the most important determinant of the use of PF.

In the multiple regression (5), where we use factor analysis to remove the correlation between the independent variables, each of our four proxies still has the expected sign. However, our economic performance proxy is no longer significant. Based on our observations in Fig. 1 and Table 4, we also consider nonlinear specifications (not reported) by using the squared values of our independent variables. Although the coefficients have the expected sign, the explanatory 
power of these nonlinear regression are generally lower. Only for economic performance does the adjusted $\mathrm{R}^{2}$ increase to $7.8 \%$ in comparison to the $6 \%$ of regression (3). However, in a multiple regression, economic performance remains nonsignificant. Overall, our findings support both our hypothesis and our theoretical model. We can also conclude that bank moral hazard is a relatively more important determinant of PF.

[Insert Table 5 about here]

We conduct additional analyses to test whether our main results are robust for different definitions of the dependent and independent variables. Table 5 also reports these results. In Panels A to E, we aggregate the independent variables political risk, corporate governance, and economic performance in different ways. In addition to the simple average, we either calculate a weighted average with weights based on the annual SL volume or we use the first or last available annual value. We also use the initial value of these variables in combination with the absolute change in this variable between the initial and last year. Within each panel, the dependent variable remains defined as project finance share based on the volume of PFLs but we also use an alternative dependent variable based on the number of PFLs.

Looking at each panel separately, we see that our model is robust to the two different definitions of our dependent variable. The sign, size, and general significance of our four explanatory factors are roughly the same. However, we note that our model can explain the variation in the number of PFLs better than it can explain the variation in terms of loan volume. The adjusted $\mathrm{R}^{2} \mathrm{~s}$ of the regressions are generally higher for the project finance share based on loan numbers. Under the multiple regression specification in Panel B, where we use weighted averages as an aggregation mechanism, we can explain almost $23 \%$ of the variation in the use of 
PFLs. This better fit for loan numbers might be driven by industry effects. For example, PFLs for construction, oil and gas, or transportation projects are among the largest, with an average deal size of more than $\$ 500$ million, compared to loans for utilities, telecommunication, or mining projects, with an average size of $\$ 395, \$ 384$, or $\$ 216$ million, respectively. Since we aggregate our data, we cannot control for these industry-driven demand effects. A dependent variable based on loan numbers does not suffer from this bias and the fit of our model is better.

The results for the different aggregation mechanism appear to be robust. We find little difference in terms of slope coefficient and explanatory power between simple averages, initial values, or last values. However, the aggregation of weighted averages leads to higher explanatory power, particularly in the multiple regressions. A weighted average is better able to capture the response of PF to the time variations in political risk and corporate governance. In contrast, these time variations cannot be captured with our specifications in Panel E. Here, the initial level of each determinant matters, but the change over the years does not.

We also investigate whether the results are robust over time. Two important events took place during our sample period, each of which affected global financial markets. These events were the Asian crisis of 1997 and the Russian crisis of 1998. Therefore, we split our sample into pre-crises, crises, and post-crises periods and aggregate the dependent and independent variables separately for each of the three periods. Our results are reported in Table 6 and indicate that the crises affect only the relation between firm moral hazard and PF. The role of DBs appears to have become more important during the crises, but the differences are not statistically significant. However, the sensitivity of PF to political risk increases significantly. Before the crises, we find that a $10 \%$ increase in political risk leads to a $3.9 \%$ higher volume of PFL relative to SL. In contrast, during and after the crises, the same $10 \%$ increase in political risk leads to a $4.1 \%$ and $5.5 \%$ higher volume of PFL relative to SL, respectively. This increased sensitivity might indicate 
that due to their experiences during the crises, lenders' perceived level of political risk has increased. Perhaps the crises changed their assessment of the benefits of PF. For example, before the crises, lenders expected to be able to manage problems arising from a (severe) deterioration in the political risk environment without resorting to PF. During the crises, they realized that this was not the case. As a consequence, they now opt for PFLs in situations in which they used to choose SLs.

[Insert Table 6 about here]

We also conduct an analysis on a country- and year-specific basis. Doing so allows us to directly control for any crisis-driven time variations on an annual level. Furthermore, we can recover any variation over the years that might be lost when we aggregate our dependent and independent variables.

We construct a panel that contains all 65 countries that access the syndicated loan market during each year between 1996 and 2004. The time restriction is necessary because our corporate governance proxy has missing values for the other years. The reduction from 139 to 65 countries allows us to create a balanced panel in which each cross-sectional country observation has the same number of time-series observations. Table 7 presents the results, which confirm our previous findings that bank influence, political risk, and corporate governance are the driving forces behind the use of PF. As the fixed time-effects show, PF was indeed used more during the crisis years. However, overall, the additional information included in the panel does not improve the explanatory power of our model. Thus, we are confident that the pooled data set applied for our main analyses is adequate. 
[Insert Table 7 about here]

\subsection{In-Depth Analysis of Bank Moral Hazard}

We wish to examine in more detail the relation between PF and bank influence, and PF and political risk. First, for bank influence we provide a proxy by measuring the aggregate market shares of all DBs including national ones. Comparing the results of regression (1) in Panel A of Table 8 with our baseline result in regression (1) of Panel A of Table 5 shows that national DBs do indeed have influence. Adding their market shares to our determinant increases the explanatory power of our model from $8.2 \%$ to $15.4 \%$.

In regression (2) of Table 8 we look at the market share of each DB category separately. The significant coefficients for multilateral DBs and national DBs indicate that both groups can influence political risk via PF, but because of their higher coefficients, national DBs are better able to do so than are multilateral DBs. Multilateral financial institutions have a nonsignificant coefficient, which indicates that even as a group, multilateral financial institutions can only influence political risk when they join forces with other DBs.

Regression (3) investigates the role of the five leading DBs in terms of individual lending share. Here, we find that individually, only the World Bank can significantly improve the influence of the syndicate. A syndicate can influence political risk in such a way that the use of PF increases by $3.2 \%$ for every $10 \%$ increase in lending share, but the impact of a syndicate that includes the World Bank is twice as high as the coefficient of $6.8 \%(=3.2 \%+3.6 \%)$ shows.

[Insert Table 8 about here] 
Panel B of Table 8 reports the results of our in-depth analysis of political risk by looking at the individual components of our political risk index. The positive, significant coefficients for each of the six components are consistent with our earlier findings: under high political risk, the borrower prefers PF. The fact that the regression results are similar implies that all forms of political risk matter.

So far, our analysis indicates that political risk can be managed with PF. Other studies show that private contracts help to mitigate the deficiencies of the legal system (Esty and Megginson, 2003; Qian and Strahan, 2005). Therefore, we wish to disentangle the effects that a poor legal system has on the use of PF, as measured by the "rule of law" and "regulatory quality" indicators on the one hand and political risk on the other. To do so, we conduct a two-step procedure. In the first step, we run the regression (political risk $=a+b$ rule of law). In the second step, we use the resulting error term as the residual political risk. We proceed similarly for regulatory quality.

Our results, which we report in regressions (10) and (11), indicate that neither rule of law nor regulatory quality can explain the whole variation in the use of PF. The influence of the residual political risk is significant as well, if only marginally so in case of rule of law. Together with the finding that our dependent variable varies systematically with bank influence, we interpret this result as evidence that the borrower uses PF to give lenders an incentive to mitigate political risk. Thus, the choice of a particular contract is motivated by both the aim to cure institutional deficiencies and by the intention to mitigate political risk.

\section{Conclusion}

We open our paper with the surprising finding that banks grant relatively more PFLs to borrowers in riskier countries. This observation indicates that limited recourse is an efficient choice that is made by the parties of the credit contract, the bank, and the firm. We explain that limited 
recourse provides a bank with the incentive to exert effort in order to reduce political risk. Thus, our model shows that the terms of a loan contract depend on the risk characteristics of the project to be financed. Thus, the terms of the credit contract are used to manage risks.

From the empirical part of our study we conclude that project finance provides very flexible structures that can be adapted to the needs of an individual project, particularly to the economic and political environment in which the project operates. Moreover, we find evidence for the role of multilateral and national DBs as political umbrellas. For commercial lenders, but also for sponsors, this result implies that they can use the participation of DBs strategically to reduce political risks. For lenders in general, political risk matters in terms of legal-system quality as well as other political risks, and PF is an effective tool to deal with high risk environments. This insight has important implications for the riskiness of PFLs and the treatment of PFLs by regulators. Unless the contracting parties make other provisions, then having no recourse can increase the loss given default. But the degree of recourse also has important incentive effects that influence the probability of default. Studying the role of collateral demonstrates that for borrower behavior, the incentive effect dominates (Liberti and Mian, 2005). A similar argument might apply to the impact of recourse on lender behavior. So far, there is very little information about the probability of default of PFLs compared to other SLs. The empirical test of this question is left for future research. 


\section{Appendix A: Proofs of Propositions 1 - 4}

\section{A.1. Proof of Proposition 1}

Depending on the parameter constellation, we can distinguish two cases:

- Case A

$$
\begin{array}{ll}
\left(\mathrm{p}_{\mathrm{H}}-\mathrm{p}_{\mathrm{L}}\right)(\mathrm{R}-\mathrm{V}) \geq \mathrm{b} & \text { for } \mathrm{V} \geq 0
\end{array}
$$

- Case B

$$
\begin{array}{ll}
\left(\mathrm{p}_{\mathrm{H}}-\mathrm{p}_{\mathrm{L}}\right) \mathrm{R} \geq \mathrm{b} & \text { for } \mathrm{V}=0
\end{array}
$$

In Case A, non-recourse as well as limited-recourse credits solve the incentive problem. In contrast to Case B, non-recourse is not a prerequisite for solving the bank's moral-hazard problem. In Case B, the bank needs higher-powered incentives, since the benefits of effort on the probability of success are not as easily reaped, either because effort $b$ is more expensive or not as powerful in terms of increasing the probability of success, i.e., $\left(\mathrm{p}_{\mathrm{H}}-\mathrm{p}_{\mathrm{L}}\right)$.

To induce the bank to exert effort, the project must be incorporated separately, and therefore the firm is not liable at all in the case of failure. If it is not possible to induce the bank to exert effort by separately incorporating the project, then the moral hazard problem of the bank cannot be solved. This case is excluded by assumption (3).

Q.E.D.

\section{A.2. Proof of Proposition 2}

For the bank, the design of the optimal contract depends on the parameter constellation. We must distinguish the following cases:

- $\quad$ Case 1

$$
(\overline{\mathrm{p}}-\underline{\mathrm{p}})(\mathrm{X}-\mathrm{R}+\mathrm{V}) \geq \mathrm{e} \quad \text { for } \mathrm{R} \geq \mathrm{V}
$$

- $\quad$ Case 2

$$
\begin{array}{ll}
(\overline{\mathrm{p}}-\underline{\mathrm{p}}) \mathrm{X} \geq \mathrm{e} & \text { for } \mathrm{R}=\mathrm{V}
\end{array}
$$


In Case 1, the bank exerts the first-best effort with either limited or full-recourse credit. Full recourse is not necessary to solve the problem, because either the difference in state-contingent payoffs of the project, $\mathrm{X}-0$, is high, or the influence of e on the probability of success is large, i.e., $(\bar{p}-\underline{p})$, which provides strong incentives to the firm's manager. In Case 2 , full recourse is necessary to induce the firm's manager to exert effort e. By increasing the debtor's liability, the payoff in the case of failure is reduced, and thus, the difference in state-contingent payoffs increases.

Q.E.D.

\section{A.3. Proof of Proposition 3}

Parameter constellations as in Case A and Case 1
Case A: $\left(p_{H}-p_{L}\right)(R-V) \geq b$
for $\mathrm{V}>0$
Case 1: $(\overline{\mathrm{p}}-\underline{\mathrm{p}})(\mathrm{X}-\mathrm{R}+\mathrm{V}) \geq \mathrm{e}$
for $\mathrm{R}>\mathrm{V}$

contain the cases in which we can solve both incentive problems simultaneously. Limited liability solves the firm's problem and the positive payoff for the bank in the case of failure does not destroy the bank's incentive.

The optimal credit contract specifies $\mathrm{R}$ and $\mathrm{V}$ according to the solution of the following optimization:

$$
\begin{array}{lll}
\max _{\mathrm{R}, \mathrm{V}, \mathrm{e}, \mathrm{b}} & \mathrm{p}_{\mathrm{H}}(\mathrm{W}+\mathrm{X}-\mathrm{R})+\left(1-\mathrm{p}_{\mathrm{H}}\right)(\mathrm{W}-\mathrm{V})-\mathrm{e} \\
\text { s.t. } & \left(\overline{\mathrm{p}_{\mathrm{H}}}-\overline{\mathrm{p}_{\mathrm{H}}}\right)(\mathrm{X}-\mathrm{R}+\mathrm{V})-\mathrm{e} \geq 0 & (\mathrm{IC}-\mathrm{F}) \\
& \left(\overline{\mathrm{p}_{\mathrm{H}}}-\overline{\overline{\mathrm{p}_{\mathrm{L}}}}\right)(\mathrm{R}-\mathrm{V})-\mathrm{b} \geq 0 & (\mathrm{IC}-\mathrm{B}) \\
& \overline{\mathrm{p}_{\mathrm{H}} \mathrm{R}}+\left(1-\overline{\mathrm{p}_{\mathrm{H}}}\right) \mathrm{V}-\mathrm{I}-\mathrm{b} \geq 0 & (\mathrm{PC}-\mathrm{B})
\end{array}
$$

The bank's participation constraint is strictly binding because there is perfect competition in the banking sector. Accordingly, the terms of the contract are given by

$$
\begin{aligned}
& R=\frac{I+b-\left(1-\overline{p_{H}}\right) V}{\overline{p_{H}}} \text { or } \\
& R-V=\frac{I+b-V}{\overline{p_{H}}}
\end{aligned}
$$


From the incentive compatibility constraints, the difference between the state contingent payoffs is determined by:

$$
\begin{array}{ll}
R-V \geq \frac{b}{\overline{p_{H}}-\overline{p_{L}}} & \text { from (IC - B) } \\
R-V \leq X-\overline{\frac{e}{\overline{p_{H}}}-\underline{p_{H}}} & \text { from (IC - F) }
\end{array}
$$

The condition, which has to hold to solve both problems simultaneously, is given by

$$
\mathrm{X} \geq \frac{1}{\overline{\mathrm{p}_{\mathrm{H}}}-\underline{\mathrm{p}_{\mathrm{H}}}} \mathrm{e}+\frac{1}{\overline{\mathrm{p}_{\mathrm{H}}}-\overline{\mathrm{p}_{\mathrm{L}}}} \mathrm{b} .
$$

If the bank's incentive compatibility constraint is binding, but the firm's incentive compatibility constraint is not, then the credit contract determines $\left\{\mathrm{R}=\mathrm{I}+\mathrm{b} \frac{1-\overline{\mathrm{p}_{\mathrm{L}}}}{\overline{\mathrm{p}_{\mathrm{H}}}-\overline{\mathrm{p}_{\mathrm{L}}}} ; \mathrm{V}=\mathrm{I}-\mathrm{b} \frac{\overline{\mathrm{p}_{\mathrm{L}}}}{\overline{\mathrm{p}_{\mathrm{H}}}-\overline{\mathrm{p}_{\mathrm{L}}}}\right\}$.

Q.E.D.

\section{A.4. Proof of Proposition 4}

In the following cases it is always impossible to solve both incentive problems.

- Case 1 and Case B:

Due to the incentive problem of the bank it is necessary that $\mathrm{V}=0$. This non-recourse structure implies for Case $1(\overline{\mathrm{p}}-\underline{\mathrm{p}})(\mathrm{X}-\mathrm{R})-\mathrm{e} \geq 0$ where $\mathrm{R}=\frac{\mathrm{I}}{\overline{\mathrm{p}}}$. However, this case is ruled out by assumption, since in this case there would be no incentive problem of the firm.

- Case 2 and Case A or Case B:

Case 2 requires $\mathrm{R}=\mathrm{V}$. But this full-recourse structure cannot solve the bank's incentive problem, because $\left(p_{H}-p_{L}\right) 0 \geq b$ is not fulfilled.

The firm maximizes its profit by solving the moral-hazard problem that has the higher return.

(1) Return of managerial effort

To solve this problem, the contract must specify $\mathrm{R}=\mathrm{V}$. Thus, the effect of e is: 


$$
\begin{aligned}
& {\left[\overline{\mathrm{p}_{\mathrm{L}}}(\mathrm{W}+\mathrm{X}-\mathrm{R})+\left(1-\overline{\mathrm{p}_{\mathrm{L}}}\right)(\mathrm{W}-\mathrm{V})-\mathrm{e}\right]-\left[\underline{\mathrm{p}_{\mathrm{L}}}(\mathrm{W}+\mathrm{X}-\mathrm{R})+\left(1-\underline{\mathrm{p}_{\mathrm{L}}}\right)(\mathrm{W}-\mathrm{V})\right]=} \\
& \left(\overline{\mathrm{p}_{\mathrm{L}}}-\underline{\mathrm{p}_{\mathrm{L}}}\right)(\mathrm{X}-\mathrm{R}+\mathrm{V})-\mathrm{e}= \\
& \left(\overline{\mathrm{p}_{\mathrm{L}}}-\underline{\mathrm{p}_{\mathrm{L}}}\right) \mathrm{X}-\mathrm{e}
\end{aligned}
$$

\section{(2) Return of bank effort}

To solve this problem, the contract must specify $V=0$ and $R$, where $R$ is such that $\overline{p R}-I-b=0$. Thus, the effect of $b$ is

$$
\begin{aligned}
& {\left[\underline{p_{H}}\left(W+X-\frac{I+b}{\underline{p_{H}}}\right)+\left(1-\underline{p_{H}}\right) W\right]-\left[\underline{p_{L}}\left(W+X-\frac{I}{\underline{p_{L}}}\right)+\left(1-\underline{p_{L}}\right) W\right]=} \\
& \left(\underline{p_{H}}-\underline{p_{L}}\right) X-b
\end{aligned}
$$

Depending on which expression is higher, the firm's manager decides which incentive problem to solve:

If $\left(\overline{p_{L}}-\underline{p_{L}}\right) X-e>\left(\underline{p_{H}}-\underline{p_{L}}\right) X-b$, then the firm's incentive problem should be solved by a credit contract that specifies $\mathrm{R}=\mathrm{V}$. For parameters like those in Case 1, the contract might also specify $\mathrm{R}>\mathrm{V}$.

If $\left(\overline{p_{L}}-\underline{p_{L}}\right) X-e<\left(\underline{p_{H}}-\underline{p_{L}}\right) X-b$, then the bank should be granted an incentive to exert effort by a credit contract specifying $\mathrm{V}=0$. In Case $\mathrm{A}$, the bank also gets the first-best incentive when it has limited recourse, $\mathrm{V}>0$.

Q.E.D. 


\section{References}

Besanko, D., Kanatas, G., 1993. Credit market equilibrium with bank monitoring and moral hazard. Review of Financial Studies 6, 213-332.

Buiter, W., Fries, S., 2002. What should the multilateral development bank do? EBRD Working Paper No. 74. European Bank for Reconstruction and Development, London.

Buljevich, E. C., Park, Y. S., 1999. Project Financing and the International Financial Markets. Kluwer Academic Publishers, Norwell, MA. and Dordrecht.

Cadwalader, 2004. Clients\&Friends Memo: Moving Towards Hybrid Project Financing. Cadwalader, Wickersham \& Taft LLP, New York.

Chemmanur, T. J., John, K., 1996. Optimal incorporation, structure of debt contracts, and limited-recourse project financing. Journal of Financial Intermediation 5, 372-408.

Djankov, S., McLiesh C., Shleifer, A., 2007. Private credit in 129 countries. Journal of Financial Economics, forthcoming.

Esty, B. C., 2004. Why study large projects? An introduction to research on project finance. European Financial Management 10, 213-224.

Esty, B. C., Megginson, W. L., 2003. Creditor rights, enforcement, and debt ownership structure: Evidence from the global syndicated loan market. Journal of Quantitative and Financial Analysis 38, 37-59.

Habib, M. A., Johnsen, B. D., 1999. The financing and redeployment of specific assets. Journal of Finance 54, 693-720.

Holmström, B., 1996. Financing of investment in Eastern Europe: A theoretical perspective. Industrial and Corporate Change 5, 205-237.

Ivashina, V., 2005. Effects of syndicate structure on loans spreads. Unpublished working paper. Stern Business School, New York.

John, T., John K., 1991. Optimality of project financing: Theory and empirical implications in finance and accounting. Review of Quantitative Finance and Accounting 1, 54-74. 
Kleimeier, S., Megginson, W. L., 1998. A comparison of project finance in Asia and the West. In: Lang, L. H. P. (Ed.), Project Finance in Asia. Advances in Finance, Investment and Banking. Vol. 6. Elsevier - North Holland, Amsterdam, pp. 57-90.

Kleimeier, S., Megginson, W. L., 2000. Are project finance loans different from other syndicated credits? Journal of Applied Corporate Finance 13, 75-87.

Kleimeier, S., Megginson, W. L., 2002. An empirical analysis of limited recourse project finance. METEOR Research Memorandum RM/02/060. Maastricht University, The Netherlands.

Laux, C., 2001. Project-specific external financing and headquarters monitoring incentives. Journal of Law, Economics, and Organization 17, 397-412.

Liberti, J., Mian, A., 2005. Uncovering collateral. Unpublished working paper. University of Chicago.

Manove, M., Padilla, A. J., Pagano, M., 2001. Collateral vs. project screening: A model of lazy banks. RAND Journal of Economics 32, 726-744.

Nguyen, H. H., Ross, D. G., 2002. Project finance risk pricing decisions: Australian evidence. Unpublished working paper. University of Western Sydney, Australia.

Qian, J., Strahan, P. E., 2005. How laws \& institutions shape financial contracts: the case of bank loans. NBER Working Paper 11052, National Bureau of Economic Research, Cambridge, Massachusetts.

Rajan, R., Winton, A., 1995. Covenants and collateral as incentives to monitor. Journal of Finance 50, 1113-1146.

Schmidt, K. M., 2003. Convertible securities and venture capital finance. Journal of Finance 58, 1139-1166.

Shah, S., Thakor, A. V., 1987. Optimal capital structure and project financing. Journal of Economic Theory 42, 209-243. 
Smith, W., 1997. Covering political and regulatory risks: Issues and options for private infrastructure arrangements. In: Irwin., T. (Ed.), Dealing with Pubic Risk in Private Infrastructure. The International Bank for Reconstruction and Development. $2^{\text {nd }}$ edition, Washington, pp. 45-88.

Sorge, M., Gadanecz, B., 2004. The term structure of credit spreads in project finance. BIS Working Paper No. 159, Bank for International Settlements, Basel, Switzerland.

Sufi, A., 2006. Information Asymmetry and Financing Arrangements: Evidence from Syndicated Loans. Journal of Finance, forthcoming. 


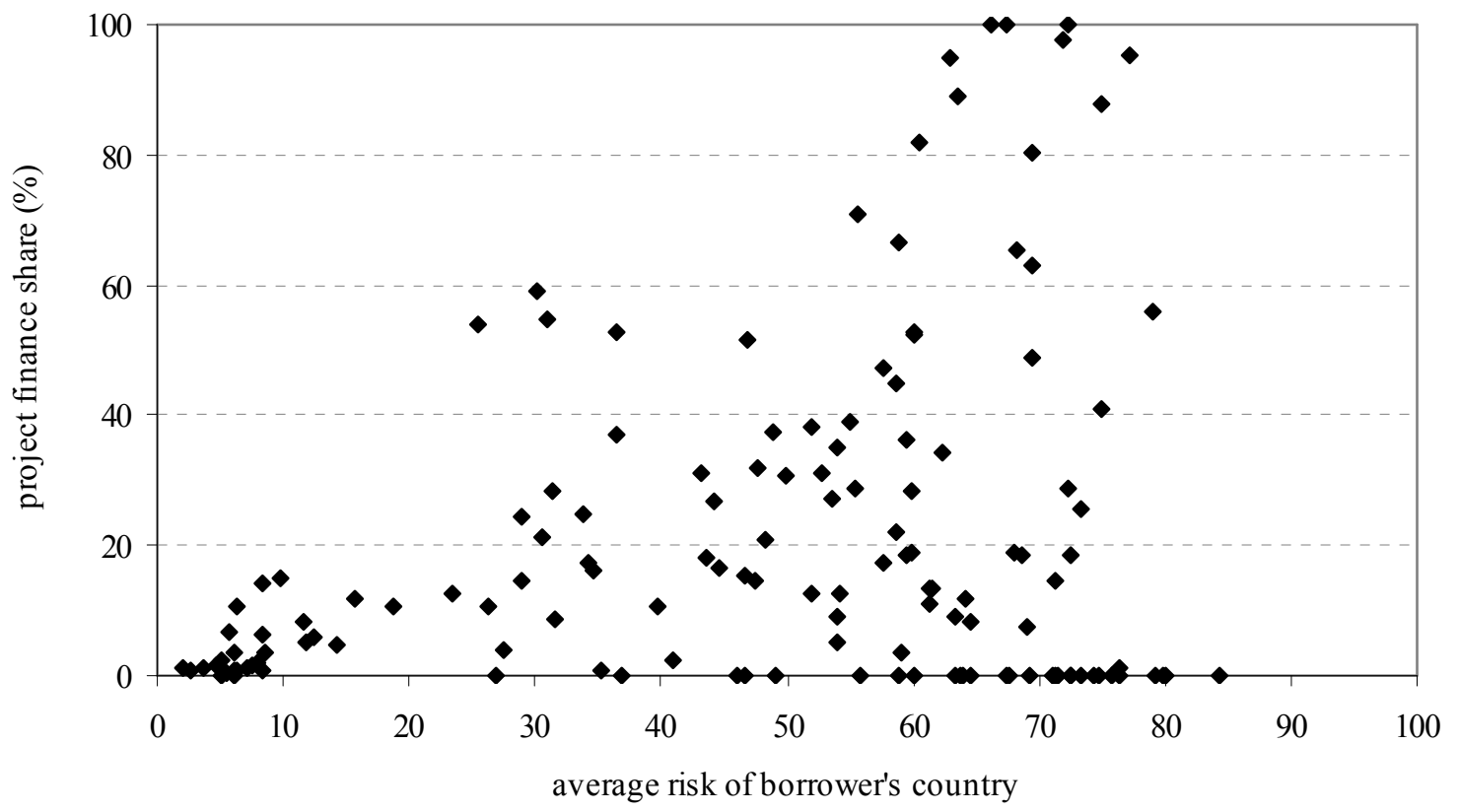

Fig. 1. The relation between the use of project finance and country risk. This figure plots the project finance share against the risk of the borrower's home country. Our sample contains 139 country-specific observations and comprises all loans signed between January 1991 and December 2005. We measure the project finance share as the total volume of project finance loans of all borrowers in a given country and express it as a percentage of the total volume of all syndicated loans of all borrowers in this country. We measure country risk as the average across all annual Euromoney's country risk scores from 1991 to 2005. We convert Euromoney's original score to a scale of zero to 100, with higher values indicating more country risk. 
Table 1

Payoffs at time 1

This table illustrates the cash flows to the project, sponsoring firm, and bank under different types of recourse in our one-period, two-states of the world model. In state 1, the project is successful and pays a cash flow of X. In state 2 , the project fails and pays zero. The loan contract specifies that the bank receives $\mathrm{R}$ in state 1 and $\mathrm{V}$ in state 2 . V indicates the amount of inside collateral and depends on the recourse structure of the loan. The project costs, which are fully loan-financed amount to I. The sponsoring firm has cash flows unrelated to the project in the amount of W.

\begin{tabular}{|c|c|c|c|c|c|}
\hline \multirow[b]{2}{*}{ Recourse structure } & \multirow[b]{2}{*}{ State } & \multirow{2}{*}{$\begin{array}{c}\text { Inside } \\
\text { collateral }\end{array}$} & \multicolumn{3}{|c|}{ Cash flows to } \\
\hline & & & Project & Sponsor & Bank lender \\
\hline \multirow[t]{2}{*}{ Full recourse } & 1 & $\mathrm{~V}=\mathrm{R}$ & $\mathrm{X}$ & $\mathrm{W}+\mathrm{X}-\mathrm{R}$ & R-I \\
\hline & 2 & $\mathrm{~V}=\mathrm{R}$ & 0 & W-R & R-I \\
\hline \multirow[t]{2}{*}{ Limited recourse } & 1 & $0<\mathrm{V}<\mathrm{R}$ & $\mathrm{X}$ & $\mathrm{W}+\mathrm{X}-\mathrm{R}$ & R-I \\
\hline & 2 & $0<\mathrm{V}<\mathrm{R}$ & 0 & $\mathrm{~W}-\mathrm{V}$ & V-I \\
\hline \multirow[t]{2}{*}{ Non recourse } & 1 & $\mathrm{~V}=0$ & $\mathrm{X}$ & $\mathrm{W}+\mathrm{X}-\mathrm{R}$ & R-I \\
\hline & 2 & $\mathrm{~V}=0$ & 0 & W & $0-\mathrm{I}$ \\
\hline
\end{tabular}


Table 2

Syndicated lending by development banks

This table lists all financial institutions, which we caterorize according to World Bank's guidelines as multilateral development banks (MDBs) or multilateral financial institutions (MFIs). The table also lists all national development banks (NDBs) with more than \$1,000 billion in funding and more than 100 syndicated loans signed between January 1, 1991 and December 31, 2005. For each financial institution we report the total amount of syndicated loans (SLs) that it funds, the share of project finance loans among all funded syndicate loans, and whether or not the financial institution is included in our bank influence proxy.

\begin{tabular}{|c|c|c|c|c|}
\hline Financial institution & Category & $\begin{array}{l}\text { Funded } \\
\text { amount } \\
\text { (in } \$ \text { bn) }\end{array}$ & $\begin{array}{r}\text { Share of } \\
\text { PFL volume } \\
\text { in SL } \\
\text { portfolio } \\
\text { (in } \%)\end{array}$ & $\begin{array}{r}\text { Inclusion } \\
\text { in the } \\
\text { bank } \\
\text { influence } \\
\text { proxy }\end{array}$ \\
\hline European Bank for Reconstruction \& Development & MDB & 31,757 & 87.0 & yes \\
\hline Kreditanstalt fur Wiederaufbau & NDB & 30,799 & 19.1 & no \\
\hline Japan Bank for International Cooperation & NDB & 26,877 & 57.3 & no \\
\hline Korea Development Bank & NDB & 19,276 & 22.7 & no \\
\hline World Bank (including IBRD and IFC) & MDB & 11,832 & 49.5 & yes \\
\hline Export Development Canada & NDB & 10,572 & 18.7 & no \\
\hline European Investment Bank & MFI & 7,881 & 81.0 & yes \\
\hline Export-Import Bank of Korea & NDB & 5,276 & 38.7 & no \\
\hline Internationale Nederlanden Bank NV & NDB & 3,983 & 5.1 & no \\
\hline Asian Development Bank & MDB & 3,691 & 50.7 & yes \\
\hline Export-Import Bank of the Republic of China & NDB & 1,117 & 19.9 & no \\
\hline Nordic Investment Bank & MFI & 860 & 27.2 & yes \\
\hline Corporacion Andina de Fomento & MDB (subregional) & 558 & 20.3 & yes \\
\hline Inter-American Development Bank & MDB & 544 & 58.3 & yes \\
\hline Islamic Development Bank & MFI & 379 & 15.7 & yes \\
\hline African Development Bank & MDB & 133 & 100.0 & yes \\
\hline Central American Bank for Economic Integration & MDB (subregional) & 36 & 68.7 & yes \\
\hline OPEC Fund & MFI & 20 & 39.4 & yes \\
\hline
\end{tabular}


Table 3

Geographic distribution of syndicated loans

The table reports descriptive statistics for all syndicated loans to borrowers in 139 countries signed between January 1,1991 and December 31, 2005 and for the average regional characteristics during this period. Based on the volume of syndicate loans and project finance loans in $\$$ million $(\$ \mathrm{~m})$, we calculate the project finance share as the volume of project finance loans in percent of syndicated loan volume. We characterize the borrower's regions in four dimensions. We measure bank influence as the volume of syndicated loans funded by multilateral development banks and multilateral financial institutions in percent of the total volume of syndicated loans. We measure economic health with Euromoney's economic performance index which includes current GDP per capita figures and on a poll of economic projections. The scale of this proxy ranges from zero to 100 . We define corporate governance as the equally weighted average of stock market capitalization and domestic credit to the private sector, both as a percentage of GDP. We use the average of six measures of political risk - voice and accountability of the government, political stability, government effectiveness, regulatory quality, rule of law, and control of corruption - from The World Bank's Worldwide Governance Research Indicators Data Set to measure political risk. The scale of this proxy ranges from zero to 100. A higher value indicates better economic health, better corporate governance, or more political risk.

\begin{tabular}{|c|c|c|c|c|c|c|c|}
\hline & \multicolumn{3}{|c|}{ Syndicate loan market characteristics } & \multicolumn{4}{|c|}{ Average characteristic of the borrower's region } \\
\hline Borrower region & $\begin{array}{r}\text { Syndicated } \\
\text { loan } \\
\text { volume } \\
\text { (in } \$ \mathrm{~m}) \\
\end{array}$ & $\begin{array}{r}\text { Project } \\
\text { finance } \\
\text { loan } \\
\text { volume } \\
\text { (in \$m) }\end{array}$ & $\begin{array}{r}\text { Project } \\
\text { finance } \\
\text { share }\end{array}$ & $\begin{array}{r}\text { Bank } \\
\text { influence }\end{array}$ & $\begin{array}{r}\text { Economic } \\
\text { health }\end{array}$ & $\begin{array}{l}\text { Corporate } \\
\text { governance }\end{array}$ & $\begin{array}{r}\text { Political } \\
\text { risk }\end{array}$ \\
\hline Middle East \& Turkey & 312,178 & 114,392 & $36.6 \%$ & 0.2 & 52 & 38 & 49 \\
\hline Eastern Europe \& CIS & 312,241 & 66,838 & $21.4 \%$ & 11.3 & 68 & 13 & 53 \\
\hline Asia \& Pacific & $2,658,199$ & 365,025 & $13.7 \%$ & 0.4 & 52 & 54 & 49 \\
\hline Latin America \& Caribbean & 410,439 & 50,209 & $12.2 \%$ & 1.4 & 58 & 30 & 48 \\
\hline Africa & 92,042 & 7,244 & $7.9 \%$ & 0.7 & 73 & 17 & 57 \\
\hline Western Europe & $6,024,295$ & 179,485 & $3.0 \%$ & 0.1 & 23 & 83 & 31 \\
\hline North America & $14,968,944$ & 157,467 & $1.1 \%$ & 0.0 & 17 & 119 & 30 \\
\hline Global & $24,778,338$ & 940,660 & $3.8 \%$ & 0.2 & 55 & 39 & 48 \\
\hline
\end{tabular}


Table 4

Changes in the use of project finance at different levels of country risk

This table illustrates how the use of project finance changes for borrowers in countries with different levels of country risk. We sort our 139 country-specific observations into four quartiles of countries with low, moderately low, moderately high, and high country risk. For each quartile we report the average country risk and average project finance volume. We measure the project finance share as the total volume of project finance loans of all borrowers in a given country as a percentage of the total volume of all syndicated loans of all borrowers in this country. We measure country risk as the average across all annual Euromoney's country risk scores from 1991 to 2005. We convert Euromoney's original score to a scale of zero to 100, with higher values indicating more country risk. The z-test indicates whether or not the average project finance share differs between the current and next higher quartile. *, **, and $* * *$ are based on one-sided probabilities and indicate that the current mean is significantly smaller than the mean of the next higher quartile at the $0.10,0.05$ and 0.01 level, respectively.

\begin{tabular}{lrrrr}
\hline $\begin{array}{l}\text { Level of country } \\
\text { risk }\end{array}$ & $\begin{array}{r}\text { Average } \\
\text { country risk }\end{array}$ & $\begin{array}{r}\text { Average project } \\
\text { finance share }\end{array}$ & z-test & $\begin{array}{r}\text { Number of } \\
\text { observations }\end{array}$ \\
\hline Low & 11.9 & $7.1 \%$ & $-4.68^{* * *}$ & 34 \\
Moderately low & 43.1 & $22.5 \%$ & $-1.59^{*}$ & 35 \\
Moderately high & 60.6 & $32.2 \%$ & 0.94 & 35 \\
High & 73.1 & $24.8 \%$ & & 35 \\
\hline
\end{tabular}


Table 5

Determinants of the use of project finance

This table shows regression results for our main proxies based on a sample of 139 country-specific observations. We define the dependent variable, project finance share, in two different ways. First, as the total volume of project finance loans of all borrowers in a given country and express it as a percentage of the total volume of all syndicated loans of all borrowers in this country. Second, as the total number of project finance loans of all borrowers in a given country and express it as a percentage of the total number of all syndicated loans of all borrowers in this country. We measure bank influence as the volume of syndicated loans funded by multilateral development banks and multilateral financial institutions in percent of the total volume of syndicated loans. We measure economic health with Euromoney's economic performance index which includes current GDP per capita figures and on a poll of economic projections. The scale of this proxy ranges from zero to 100. We define corporate governance as the equally weighted average of stock market capitalization and domestic credit to the private sector, both as a percentage of GDP. We use the average of six measures of political risk - voice and accountability of the government, political stability, government effectiveness, regulatory quality, rule of law, and control of corruption - from The World Bank's Worldwide Governance Research Indicators Data Set to measure political risk. The scale of this proxy ranges from zero to 100. A higher value indicates better economic health, better corporate governance, or more political risk. In each panel we use a different aggregation method for the independent variables political risk, corporate governance, and economic health. In addition to the simple average, we aggregate annual values by (A) calculating a simple, equally weighted averages over time, (B) calculating a weighted average with weights based on the relative syndicated loan volume, (C) using the first or (D) last available annual value, (E) by using the initial value in combination with the change over time. We calculate this change as absolute difference between the values in the initial and last year. The calculation of the bank influence proxy does not change and we report the results for comparison reasons only. We estimate single regressions as OLS, but use factor analysis in multiple regressions to remove the correlation between the independent variables. The table reports $t$-statistics within parentheses.

\begin{tabular}{|c|c|c|c|c|c|c|c|c|c|c|}
\hline & \multicolumn{5}{|c|}{$\begin{array}{l}\text { Dependent variable: Project finance share based } \\
\text { on loan volume }\end{array}$} & \multicolumn{5}{|c|}{$\begin{array}{l}\text { Dependent variable: Project finance share } \\
\text { based on loan numbers }\end{array}$} \\
\hline & (1) & (2) & (3) & (4) & (5) & (6) & (7) & (8) & (9) & (10) \\
\hline \multicolumn{11}{|c|}{ Panel A: Simple average } \\
\hline Bank influence & $\begin{array}{c}0.48 \\
(3.66)\end{array}$ & & & & $\begin{array}{c}7.39 \\
(3.50)\end{array}$ & $\begin{array}{r}0.47 \\
(4.25)\end{array}$ & & & & $\begin{array}{r}7.26 \\
(4.06)\end{array}$ \\
\hline Political risk & & $\begin{array}{c}0.68 \\
(3.57)\end{array}$ & & & $\begin{array}{l}5.77 \\
(2.73)\end{array}$ & & $\begin{array}{r}0.61 \\
(3.74)\end{array}$ & & & $\begin{array}{r}4.90 \\
(2.74)\end{array}$ \\
\hline Economic health & & & $\begin{array}{c}-0.32 \\
(-3.16)\end{array}$ & & $\begin{array}{l}-5.17 \\
(-0.01)\end{array}$ & & & $\begin{array}{r}-0.30 \\
(-3.47)\end{array}$ & & $\begin{array}{r}-0.53 \\
(-0.30)\end{array}$ \\
\hline $\begin{array}{l}\text { Corporate } \\
\text { governance }\end{array}$ & & & & $\begin{array}{l}-0.19 \\
(-3.47)\end{array}$ & $\begin{array}{l}-4.64 \\
(-2.45)\end{array}$ & & & & $\begin{array}{r}-0.17 \\
(-3.71)\end{array}$ & $\begin{array}{c}-4.64 \\
(-2.60)\end{array}$ \\
\hline Constant & $\begin{array}{l}18.46 \\
(7.86)\end{array}$ & $\begin{array}{l}-10.72 \\
(-1.15)\end{array}$ & $\begin{array}{l}35.98 \\
(7.18)\end{array}$ & $\begin{array}{l}29.05 \\
(9.59)\end{array}$ & $\begin{array}{c}21.76 \\
(10.34)\end{array}$ & $\begin{array}{l}15.92 \\
(8.00)\end{array}$ & $\begin{array}{l}-10.02 \\
(-1.25)\end{array}$ & $\begin{array}{l}32.50 \\
(7.60)\end{array}$ & $\begin{array}{l}25.83 \\
(9.98)\end{array}$ & $\begin{array}{r}19.17 \\
(10.76)\end{array}$ \\
\hline Adjusted $\mathrm{R}^{2}$ & 0.082 & 0.078 & 0.061 & 0.074 & 0.136 & 0.110 & 0.086 & 0.070 & 0.080 & 0.163 \\
\hline \multicolumn{11}{|c|}{ Panel B: Weighted average } \\
\hline Bank influence & $\begin{array}{c}0.48 \\
(3.66)\end{array}$ & & & & $\begin{array}{c}9.83 \\
(4.63)\end{array}$ & $\begin{array}{r}0.47 \\
(4.25)\end{array}$ & & & & $\begin{array}{r}9.59 \\
(5.40)\end{array}$ \\
\hline Political risk & & $\begin{array}{c}0.68 \\
(3.44)\end{array}$ & & & $\begin{array}{l}4.83 \\
(2.28)\end{array}$ & & $\begin{array}{r}0.61 \\
(3.60)\end{array}$ & & & $\begin{array}{r}4.04 \\
(2.28)\end{array}$ \\
\hline Economic health & & & $\begin{array}{c}-0.35 \\
(-3.37)\end{array}$ & & $\begin{array}{c}-1.66 \\
(-0.78)\end{array}$ & & & $\begin{array}{c}-0.32 \\
(-3.68)\end{array}$ & & $\begin{array}{r}-2.00 \\
(-1.13)\end{array}$ \\
\hline $\begin{array}{l}\text { Corporate } \\
\text { governance }\end{array}$ & & & & $\begin{array}{l}-0.18 \\
(-3.53)\end{array}$ & $\begin{array}{l}-5.34 \\
(-2.52)\end{array}$ & & & & $\begin{array}{r}-0.16 \\
(-3.72)\end{array}$ & $\begin{array}{c}-4.67 \\
(-2.63)\end{array}$ \\
\hline Constant & $\begin{array}{l}18.46 \\
(7.86)\end{array}$ & $\begin{array}{l}-9.92 \\
(-1.01)\end{array}$ & $\begin{array}{l}36.85 \\
(7.40)\end{array}$ & $\begin{array}{l}29.17 \\
(9.64)\end{array}$ & $\begin{array}{c}22.91 \\
(10.83)\end{array}$ & $\begin{array}{l}15.92 \\
(8.00)\end{array}$ & $\begin{array}{c}-9.25 \\
(-1.10)\end{array}$ & $\begin{array}{l}33.24 \\
(7.81)\end{array}$ & $\begin{array}{l}25.87 \\
(9.99)\end{array}$ & $\begin{array}{r}20.18 \\
(11.42)\end{array}$ \\
\hline Adjusted $\mathrm{R}^{2}$ & 0.080 & 0.076 & 0.070 & 0.080 & 0.184 & 0.110 & 0.084 & 0.080 & 0.090 & 0.228 \\
\hline
\end{tabular}


Table 5 continued

\begin{tabular}{|c|c|c|c|c|c|c|c|c|c|c|}
\hline & \multicolumn{5}{|c|}{$\begin{array}{l}\text { Dependent variable: Project finance share based } \\
\text { on loan volume }\end{array}$} & \multicolumn{5}{|c|}{$\begin{array}{l}\text { Dependent variable: Project finance share } \\
\text { based on loan numbers }\end{array}$} \\
\hline & $(1)$ & (2) & (3) & (4) & (5) & (6) & $(7)$ & $(8)$ & (9) & $(10)$ \\
\hline \multicolumn{11}{|c|}{ Panel C: First value } \\
\hline \multirow[t]{2}{*}{ Bank influence } & 0.48 & & & & 7.53 & 0.47 & & & & 7.37 \\
\hline & $(3.66)$ & & & & $(3.57)$ & $(4.25)$ & & & & $(4.11)$ \\
\hline \multirow[t]{2}{*}{ Political risk } & & 0.67 & & & 5.52 & & 0.59 & & & 4.40 \\
\hline & & $(3.48)$ & & & $(2.61)$ & & $(3.55)$ & & & $(2.46)$ \\
\hline \multirow[t]{2}{*}{ Economic health } & & & -0.22 & & -0.72 & & & 0.21 & & -1.23 \\
\hline & & & $(-2.68)$ & & $(-0.34)$ & & & $(-3.03)$ & & $(-0.68)$ \\
\hline \multirow{2}{*}{$\begin{array}{l}\text { Corporate } \\
\text { governance }\end{array}$} & & & & -0.25 & -5.10 & & & & -0.23 & -4.62 \\
\hline & & & & $(-3.35)$ & $(-2.41)$ & & & & $(-3.57)$ & $(-2.58)$ \\
\hline \multirow[t]{2}{*}{ Constant } & 18.46 & -10.43 & 32.60 & 28.87 & 21.76 & 15.92 & -9.05 & 29.63 & 25.65 & 19.17 \\
\hline & $(7.86)$ & $(-1.10)$ & $(7.08)$ & $(9.48)$ & $(10.33)$ & $(8.00)$ & $(-1.11)$ & (7.53) & $(9.84)$ & (10.74) \\
\hline Adjusted $\mathrm{R}^{2}$ & 0.080 & 0.075 & 0.040 & 0.070 & 0.135 & 0.110 & 0.078 & 0.060 & 0.080 & 0.159 \\
\hline \multicolumn{11}{|c|}{ Panel D: Last value } \\
\hline \multirow[t]{2}{*}{ Bank influence } & 0.48 & & & & 7.07 & 0.47 & & & & 7.04 \\
\hline & $(3.66)$ & & & & (3.34) & $(4.25)$ & & & & (3.93) \\
\hline \multirow[t]{2}{*}{ Political risk } & & 0.65 & & & 5.95 & & 0.59 & & & 5.20 \\
\hline & & $(3.59)$ & & & $(2.81)$ & & $(3.80)$ & & & $(2.90)$ \\
\hline \multirow[t]{2}{*}{ Economic health } & & & -0.28 & & -0.88 & & & -0.26 & & -1.13 \\
\hline & & & $(-2.90)$ & & $(-0.42)$ & & & $(-3.16)$ & & $(-0.63)$ \\
\hline \multirow{2}{*}{$\begin{array}{l}\text { Corporate } \\
\text { governance }\end{array}$} & & & & -0.16 & -4.99 & & & & -0.14 & -4.40 \\
\hline & & & & $(-3.44)$ & $(-2.35)$ & & & & $(-3.66)$ & $(-2.46)$ \\
\hline \multirow[t]{2}{*}{ Constant } & 18.46 & -10.15 & 32.00 & 28.95 & 21.76 & 15.92 & -9.73 & 28.73 & 25.71 & 19.17 \\
\hline & $(7.86)$ & $(-1.11)$ & (7.68) & $(9.59)$ & $(10.31)$ & $(8.00)$ & $(-1.24)$ & $(8.06)$ & $(9.95)$ & $(10.75)$ \\
\hline Adjusted $\mathrm{R}^{2}$ & 0.080 & 0.079 & 0.050 & 0.070 & 0.131 & 0.110 & 0.060 & 0.06 & 0.080 & 0.160 \\
\hline \multicolumn{11}{|c|}{ Panel E: Mixed values } \\
\hline \multirow{2}{*}{$\begin{array}{l}\text { Initial political } \\
\text { risk }\end{array}$} & -0.29 & & & & & 0.59 & & & & \\
\hline & $(-2.93)$ & & & & & (3.57) & & & & \\
\hline \multirow{2}{*}{$\begin{array}{l}\text { Change in } \\
\text { political risk }\end{array}$} & -0.20 & & & & & 0.63 & & & & \\
\hline & $(-1.23)$ & & & & & $(1.29)$ & & & & \\
\hline \multirow{2}{*}{$\begin{array}{l}\text { Initial economic } \\
\text { health }\end{array}$} & & 0.67 & & & & & -0.27 & & & \\
\hline & & $(3.48)$ & & & & & $(-3.21)$ & & & \\
\hline \multirow{2}{*}{$\begin{array}{l}\text { Change in } \\
\text { economic health }\end{array}$} & & 0.51 & & & & & -0.17 & & & \\
\hline & & $(0.89)$ & & & & & $(-1.22)$ & & & \\
\hline \multirow{2}{*}{$\begin{array}{l}\text { Initial corporate } \\
\text { governance }\end{array}$} & & & -0.21 & & & & & -0.19 & & \\
\hline & & & $(-2.50)$ & & & & & $(-2.68)$ & & \\
\hline $\begin{array}{l}\text { Change in } \\
\text { corporate } \\
\text { governance }\end{array}$ & & & $\begin{array}{c}-0.10 \\
(-1.07)\end{array}$ & & & & & $\begin{array}{c}-0.09 \\
(-1.11)\end{array}$ & & \\
\hline \multirow[t]{2}{*}{ Constant } & 33.26 & -10.83 & 29.42 & & & -9.54 & 30.19 & 26.14 & & \\
\hline & $(7.19)$ & $(1.14)$ & $(9.53)$ & & & $(-1.17)$ & $(7.63)$ & $(9.90)$ & & \\
\hline Adjusted $\mathrm{R}^{2}$ & 0.047 & 0.073 & 0.070 & & & 0.082 & 0.059 & 0.080 & & \\
\hline
\end{tabular}


Table 6

Robustness checks regarding the effects of the Asian and Russian crises

We aggregate the data into three separate periods: a pre-crises period from 1991 to 1997, a crises period from 1998 to 1999 , and a post-crises period from 2000 to 2005 . For each period, we define the dependent variable as the total volume of project finance loans of all borrowers in a given country and express it as a percentage of the total volume of all syndicated loans of all borrowers in this country. We measure bank influence as the volume of syndicated loans funded by multilateral development banks and multilateral financial institutions in percent of the total volume of syndicated loans. We measure economic health with Euromoney's economic performance index which includes current GDP per capita figures and on a poll of economic projections. The scale of this proxy ranges from zero to 100 . We define corporate governance as the equally weighted average of stock market capitalization and domestic credit to the private sector, both as a percentage of GDP. We use the average of six measures of political risk - voice and accountability of the government, political stability, government effectiveness, regulatory quality, rule of law, and control of corruption - from The World Bank's Worldwide Governance Research Indicators Data Set to measure political risk. The scale of this proxy ranges from zero to 100 . A higher value indicates better economic health, better corporate governance, or more political risk. For all independent variables, we calculate simple averages across each subperiod. We estimate regressions as OLS. The table reports $t$ statistics within parentheses. The F-test indicates whether or not the slope coefficients differ across periods. ${ }^{*}, * *$, and $* * *$ indicate significant differences at the $0.10,0.05$ and 0.01 level, respectively.

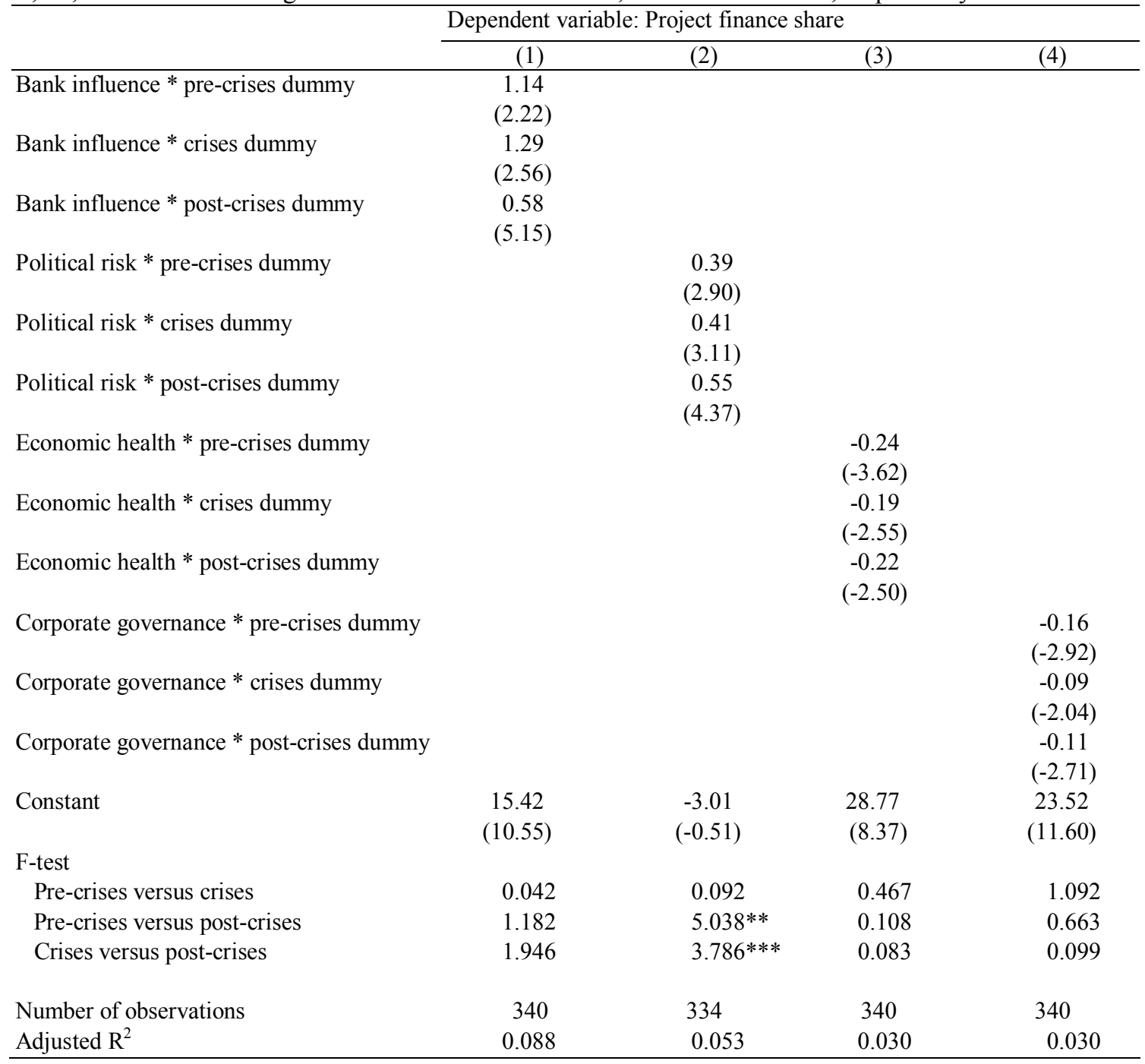


Table 7

Panel data robustness checks regarding the determinants of the use of project finance

This table shows regression results for our main proxies based on a panel of 585 observations taken for 65 countries and nine years. We define the dependent variable as the total volume of project finance loans of all borrowers in a given country and year and express it as a percentage of the total volume of all syndicated loans of all borrowers in this country and year. Second, as the total number of project finance loans of all borrowers in a given country and express it as a percentage of the total number of all syndicated loans of all borrowers in this country. We measure bank influence as the volume of syndicated loans funded by multilateral development banks and multilateral financial institutions in percent of the total volume of syndicated loans. We measure economic health with Euromoney's economic performance index which includes current GDP per capita figures and on a poll of economic projections. The scale of this proxy ranges from zero to 100 . We define corporate governance as the equally weighted average of stock market capitalization and domestic credit to the private sector, both as a percentage of GDP. We use the average of six measures of political risk - voice and accountability of the government, political stability, government effectiveness, regulatory quality, rule of law, and control of corruption - from The World Bank's Worldwide Governance Research Indicators Data Set to measure political risk. The scale of this proxy ranges from zero to 100 . A higher value indicates better economic health, better corporate governance, or more political risk. In Panel A, we estimate a fixed effects model which contains year-specific intercepts. We estimate regressions as OLS. In panel $\mathrm{B}$, we estimate single regressions as OLS, but use factor analysis in multiple regressions to remove the correlation between the independent variables. The table reports $t$-statistics within parentheses.

\begin{tabular}{lccccc}
\hline \multicolumn{5}{c}{ Dependent variable: Project finance share } & \\
\cline { 2 - 6 } & $(1)$ & $(2)$ & $(3)$ & $(4)$ & $(5)$ \\
\hline Panel A: Fixed effects model & & & & & \\
Bank influence & 0.50 & & & & 6.04 \\
& $(2.09)$ & & & & $(5.95)$ \\
Political risk & & 0.63 & & & 1.95 \\
& & $(7.41)$ & & & $(1.64)$ \\
Economic health & & & -0.26 & & -0.49 \\
& & & $(-6.67)$ & & $(-0.46)$ \\
Corporate governance & & & & -0.09 & -3.36 \\
& & & & $(-6.56)$ & $(-5.07)$ \\
1996-dummy & 9.44 & -16.38 & 28.48 & 14.95 & 6.74 \\
& $(4.56)$ & $(-4.24)$ & $(7.52)$ & $(6.28)$ & $(2.76)$ \\
1997-dummy & 12.41 & -13.50 & 30.98 & 18.11 & 10.14 \\
& $(5.79)$ & $(-3.60)$ & $(8.59)$ & $(7.70)$ & $(4.73)$ \\
1998-dummy & 15.22 & -9.54 & 33.95 & 22.07 & 14.26 \\
& $(5.89)$ & $(-2.41)$ & $(8.64)$ & $(7.91)$ & $(5.40)$ \\
1999-dummy & 17.80 & -7.38 & 31.37 & 24.55 & 20.37 \\
& $(5.55)$ & $(-1.88)$ & $(7.83)$ & $(7.16)$ & $(6.50)$ \\
2000-dummy & 12.07 & -13.36 & 25.70 & 19.55 & 14.68 \\
& $(5.27)$ & $(-3.60)$ & $(7.67)$ & $(6.99)$ & $(5.99)$ \\
2001-dummy & 15.63 & -9.50 & 29.19 & 23.20 & 18.54 \\
& $(5.13)$ & $(-2.30)$ & $(7.51)$ & $(6.95)$ & $(6.20)$ \\
2002-dummy & 13.12 & -11.34 & 28.08 & 20.87 & 15.54 \\
& $(4.68)$ & $(-2.93)$ & $(7.68)$ & $(6.89)$ & $(5.71)$ \\
2003-dummy & 11.20 & -13.49 & 25.74 & 18.77 & 13.61 \\
& $(3.82)$ & $(-3.23)$ & $(7.10)$ & $(6.31)$ & $(4.87)$ \\
2004-dummy & 16.42 & -9.52 & 31.13 & 23.51 & 17.45 \\
& $(4.94)$ & $(-2.30)$ & $(7.25)$ & $(6.60)$ & $(5.56)$ \\
Adjusted R ${ }^{2}$ & & & & & \\
& 0.014 & 0.084 & 0.053 & 0.045 & 0.092 \\
\hline
\end{tabular}


Table 7 continued

\begin{tabular}{|c|c|c|c|c|c|}
\hline & \multicolumn{5}{|c|}{ Dependent variable: Project finance share } \\
\hline \multirow{2}{*}{\multicolumn{6}{|c|}{ Panel B: Random effects model }} \\
\hline & & & & & \\
\hline Bank influence & $\begin{array}{c}0.50 \\
(3.06)\end{array}$ & & & & $\begin{array}{c}5.16 \\
(5.89)\end{array}$ \\
\hline Political risk & & $\begin{array}{c}0.62 \\
(7.32)\end{array}$ & & & $\begin{array}{c}2.08 \\
(2.37)\end{array}$ \\
\hline Economic health & & & $\begin{array}{c}-0.24 \\
(-5.81)\end{array}$ & & $\begin{array}{l}-2.58 \\
(-2.95)\end{array}$ \\
\hline Corporate governance & & & & $\begin{array}{l}-0.09 \\
(-5.13)\end{array}$ & $\begin{array}{l}-2.71 \\
(-3.10)\end{array}$ \\
\hline Constant & $\begin{array}{l}13.70 \\
(14.27)\end{array}$ & $\begin{array}{l}-11.48 \\
(-3.13)\end{array}$ & $\begin{array}{c}28.13 \\
(11.27)\end{array}$ & $\begin{array}{c}20.38 \\
(14.45)\end{array}$ & $\begin{array}{l}14.59 \\
(16.67)\end{array}$ \\
\hline Adjusted $\mathrm{R}^{2}$ & 0.014 & 0.082 & 0.053 & 0.041 & 0.084 \\
\hline
\end{tabular}


Table 8

An in-depth analysis of the role of bank moral hazard

This table shows regression results for our sample of 139 country-specific observations. We define the dependent variable as the total volume of project finance loans of all borrowers in a given country and express it as a percentage of the total volume of all syndicated loans of all borrowers in this country. In Panel A, we measure bank influence as the volume of syndicated loans funded by development banks in percent of the total volume of syndicated loans. We distinguish between three different categories of development banks: multilateral development banks (MDBs), multilateral financial institutions (MFIs), and national development banks (NDBs). In regressions (1) and (3) we aggregate all three categories whereas we investigate them separately in regression (2). In regression (3) we also employ bank-specific dummy variables in combination with our market share proxy. These dummies are coded as one if the respective development bank is part of the syndicate and zero otherwise. This allows us to investigate whether the addition of a particular development bank increases the influence of the group as a whole. Only those development banks are considered that lend to at least 30 of our 139 countries. These are the European Bank for Reconstruction and Development (EBRD), World Bank (WB), Kreditanstalt für Wiederaufbau (KfW), Japan Bank for International Cooperation (JBIC), and Export Development Canada (ExCan). In Panel B, we measure political risk using the six individual measures provided by The World Bank's Worldwide Governance Research Indicators Data Set. Political risk as used in regressions (10) and (11) is defined as the simple average of these six individual measures. To avoid multicollinearity problems we do not use this proxy directly but regress it on our proxies for rule of law and regulatory quality, respectively. We use the regression residuals as the residual political risk proxy in regressions (10) and (11), respectively. We estimate all regressions as OLS. The table reports $t$-statistics within parentheses.

Dependent variable:

Project finance share

(1) (2) (3)

Panel A: Bank influence

Aggregate market share of all MDBs, MFIs, and NDBs

0.56

(5.11)

Aggregate market share of all MDBs

Aggregate market share of all MFIs

Aggregate market share of all NDBs

Aggregate market share of all MDBs, MFIs, and NDBs

Aggregate market share of all MDBs, MFIs, and NDBs * EBRD dummy

Aggregate market share of all MDBs, MFIs, and NDBs * WB dummy

Aggregate market share of all MDBs, MFIs, and NDBs * KfW dummy

Aggregate market share of all MDBs, MFIs, and NDBs * JBIC dummy

0.29

Aggregate market share of all MDBs, MFIs, and NDBs * ExCan dummy

0.10

$(0.27)$

Constant

$16.28 \quad 16.05$

15.07

$(6.95) \quad(6.81) \quad(6.10)$

Adjusted $\mathrm{R}^{2}$

$\begin{array}{lll}0.154 & 0.151 & 0.174\end{array}$


Table 8 continued

\begin{tabular}{|c|c|c|c|c|c|c|c|c|}
\hline & \multicolumn{8}{|c|}{ Dependent variable: Project finance share } \\
\hline \multirow{2}{*}{ Panel B: Political risk } & (4) & (5) & (6) & (7) & (8) & (9) & (10) & (11) \\
\hline & & & & & & & & \\
\hline Control of corruption & $\begin{array}{c}0.66 \\
(4.06)\end{array}$ & & & & & & & \\
\hline Government effectiveness & & $\begin{array}{c}0.58 \\
(3.40)\end{array}$ & & & & & & \\
\hline Political stability & & & $\begin{array}{c}0.58 \\
(2.96)\end{array}$ & & & & & \\
\hline Voice and accountability & & & & $\begin{array}{c}0.69 \\
(3.75)\end{array}$ & & & & \\
\hline Regulatory quality & & & & & $\begin{array}{c}0.48 \\
(2.46)\end{array}$ & & & $\begin{array}{c}0.48 \\
(2.56)\end{array}$ \\
\hline Rule of law & & & & & & $\begin{array}{c}0.57 \\
(3.30)\end{array}$ & $\begin{array}{c}0.57 \\
(3.32)\end{array}$ & \\
\hline Residual political risk & & & & & & & $\begin{array}{l}1.44 \\
(1.55)\end{array}$ & $\begin{array}{c}1.88 \\
(3.52)\end{array}$ \\
\hline Constant & $\begin{array}{l}-9.85 \\
(-1.22)\end{array}$ & $\begin{array}{l}-5.93 \\
(-0.70)\end{array}$ & $\begin{array}{l}-6.37 \\
(-0.65)\end{array}$ & $\begin{array}{l}-12.04 \\
(-1.30)\end{array}$ & $\begin{array}{l}-0.90 \\
(-0.10)\end{array}$ & $\begin{array}{l}-5.39 \\
(-0.63)\end{array}$ & $\begin{array}{l}-5.39 \\
(-0.64)\end{array}$ & $\begin{array}{l}-0.90 \\
(-0.10)\end{array}$ \\
\hline Adjusted $\mathrm{R}^{2}$ & 0.101 & 0.071 & 0.053 & 0.087 & 0.035 & 0.067 & 0.080 & 0.110 \\
\hline
\end{tabular}

